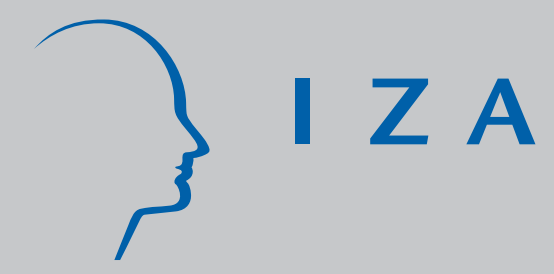

IZADP No. 1501

Accounting for Differences in Labour Market Outcomes in Great Britain: A Regional Analysis Using the Labour Force Survey

Nigel O'Leary

Philip D. Murphy

Paul Latreille

David H. Blackaby

Peter J . Sloane

February 2005 


\title{
Accounting for Differences in Labour Market Outcomes in Great Britain: A Regional Analysis Using the Labour Force Survey
}

\author{
Nigel O'Leary \\ University of Wales Swansea \\ Philip D. Murphy \\ University of Wales Swansea \\ Paul Latreille \\ University of Wales Swansea \\ David H. Blackaby \\ University of Wales Swansea \\ Peter J. Sloane \\ University of Wales Swansea and IZA Bonn
}

Discussion Paper No. 1501

February 2005

IZA

P.O. Box 7240
53072 Bonn
Germany

Phone: +49-228-3894-0

Fax: +49-228-3894-180

Email: iza@iza.org

\begin{abstract}
Any opinions expressed here are those of the author(s) and not those of the institute. Research disseminated by IZA may include views on policy, but the institute itself takes no institutional policy positions.

The Institute for the Study of Labor (IZA) in Bonn is a local and virtual international research center and a place of communication between science, politics and business. IZA is an independent nonprofit company supported by Deutsche Post World Net. The center is associated with the University of Bonn and offers a stimulating research environment through its research networks, research support, and visitors and doctoral programs. IZA engages in (i) original and internationally competitive research in all fields of labor economics, (ii) development of policy concepts, and (iii) dissemination of research results and concepts to the interested public.
\end{abstract}

IZA Discussion Papers often represent preliminary work and are circulated to encourage discussion. Citation of such a paper should account for its provisional character. A revised version may be available directly from the author. 


\section{ABSTRACT \\ Accounting for Differences in Labour Market Outcomes in Great Britain: A Regional Analysis Using the Labour Force Survey*}

Regional unemployment rates in Great Britain have narrowed dramatically in recent years. However, significant differences still remain in terms of both employment and economic inactivity rates, which may now better reflect relative labour market performance. This paper examines these differences in labour market outcomes using a unified empirical framework that decomposes regional differences in employment, economic inactivity and unemployment into components due to either structural or composition effects. The analysis highlights the important role that ill health and structural deficits currently play in accounting for regional differences in both employment and economic inactivity rates.

JEL Classification: J21

Keywords: regions, employment, unemployment, inactivity

Corresponding author:

Peter J. Sloane

Department of Economics

University of Wales Swansea

Singleton Park

Swansea, SA2 8PP

United Kingdom

Email: p.j.sloane@swansea.ac.uk

\footnotetext{
* Funding from the National Assembly for Wales is gratefully acknowledged. However, the views expressed in this paper are not those of the National Assembly. Data from the Labour Force Survey is Crown Copyright, has been made available from the Office for National Statistics (ONS) through the UK Data Archive and used by permission. Neither the ONS nor the Data Archive bear any responsibility for the analysis or interpretation of the data reported here.
} 


\section{Introduction}

In a foreword to Towards Full Employment in a Modern Society (2001), the Prime Minister Tony Blair states: "Our goal is clear: to create and then sustain employment opportunities for all over the next decade - in every part of the country". This statement re-affirmed and gave focus to a long-standing commitment made by the newly elected Labour Government in 1997 to achieve stable levels of growth in prosperity and employment in all regions of the UK by improving overall labour market performance. Given that persistently low levels of economic performance are a major problem for some UK regions however, the scale of the challenge represented by this aspiration to "level up" should not be under-estimated. For example, GDP per capita in Northern Ireland, Wales and the North East is nearly 40 per cent below that found in London and the South East (Treasury, 2003), and has been lower in these regions for at least a generation.

The strategy implemented by the Government to achieve its objectives has been both complex and multi-faceted. However, two key principles underpin much of what has been done, particularly with regard to the labour market. First, economic stability is seen as a necessary prerequisite to improving labour market performance, and the Government has sought to foster this by adopting new and transparent frameworks for both monetary and fiscal policy. Central Bank independence, inflation targeting, and new rules governing the use of debt financing are all features of new monetary and fiscal reforms that the Government has used to promote economic stability and so end the 'boom-bust' cycle that many commentators have identified as being a fundamental weakness of the UK economy since the end of the Second World War. Second, and no less importantly, the Government has introduced a number of new initiative that seek 
to encourage people back into work by making work pay (e.g. the introduction of the National Minimum Wage in April 1999, various New Deal programmes and the use of Working Tax Credits).

Allied with these two principles, the Government has created a devolved administrative framework designed to attune decision-making more closely to the needs of individual regions through the establishment of National Assemblies in Wales and Scotland and Regional Development Agencies in England. However, while these new arrangements allow regions to determine their own priorities, and seem to be better suited to targeting existing resources more efficiently, they have been largely accommodated from within existing spending plans which are unlikely to provide the poorest placed regions with the level of resources they need to make a difference ${ }^{1}$.

Notwithstanding these devolved bodies, as the above discussion might suggest, the Government's view as to what constitutes a modern regional policy has evidenced a major shift in focus in recent years, away from policies designed to help only the poorest placed regions, towards policies that seek to improve performance in all regions. This approach to regional policy, most clearly articulated in A Modern Regional Policy for the United Kingdom, might in essence be described as one that primarily targets "people not places", and continues a trend started by successive Conservative administrations between 1979 and 1997, whereby old-style demand-led policies were systematically replaced by supply-side policies designed to help the disadvantaged find work, regardless of where they lived. Such an approach has been

\footnotetext{
${ }^{1}$ The loss of support from European Structural Funds, as a consequence of EU enlargement, is likely to be a major concern for some UK regions, and in this respect the government's commitment to the proposals it has already made about the provision of transitional funding from 2006 is likely to be very important (see HM Treasury 2003).
} 
further reiterated and reinforced by the 80 per cent employment rate target and by the much-publicised reforms of incapacity benefits in the recent Department for Work and Pensions Five Year Strategy: Opportunity and security throughout life (Department for Work and Pensions, 2005). Given that there are pockets of disadvantaged individuals in almost every region, such a policy does at face value seem sensible ${ }^{2}$. However, the policy does suffer from one important drawback: while the government's approach is able to make work more attractive, and indeed to eliminate certain market failures that might otherwise impede the efficient longerterm functioning of the market mechanism, it does little to tackle any regional imbalances in demand that might otherwise prevent individuals in the poorest performing regions finding work.

Outwardly at least the government strategy seems to have been successful. Employment rates are rising (to almost 75 per cent), unemployment is falling, and inflation is low. A closer inspection of the evidence, however, suggests the government's record may not be as impressive as it first appears. Chart 1, for example, shows that improvements in both employment and unemployment pre-date the series of reforms introduced since 1997, and that things had started to improve from as early as 1993 onwards. Similarly, Nickell and Quintini (2002) have shown that while equilibrium unemployment has been steadily falling in the UK since the mid-1980s, most of this improvement was the result of actions taken by previous Conservative Governments and was not the result of policies pursued since 1997. Indeed, according to Nickell and Quintini (2002), not only have Government policies adopted since 1997 had only a modest effect on equilibrium unemployment, they are

\footnotetext{
${ }^{2}$ In recognition of the very localised nature of 'pockets of deprivation', the 'Five Year Strategy' commits to a refocusing of effort from local authority district level to the more spatially disaggregated ward level.
} 
also unlikely to resolve the high levels of worklessness currently found among many low skilled groups, which Nickell and Quintini identify as being one of the most pressing problems presently facing the UK labour market. Moreover, it is a problem that seems to have a distinctive regional dimension, in which depressed 'Northern' regions tend to have much higher levels of worklessness than more prosperous 'Southern' regions.

Erdem and Glynn (2001) also highlight important spatial differences in labour market performance within the UK. They show that while the dispersion of regional unemployment rates has fallen dramatically over the 1990s, significant differences still remain in terms of non-employment rates. These tend to be most prominent for the least qualified individuals, and remarkably stable over time. According to Erdem and Glyn (2001) there is a substantial North-South divide in terms of regional employment rates, which they estimated would require an additional 1.75 million jobs to eliminate. Indeed, relative to more prosperous Southern regions, Northern regions face a double labour market disadvantage: not only are employment rates lower for the least qualified in Northern regions, but Northern regions also have a much higher proportion of less qualified individuals.

Given that certain groups of individuals are more likely to occupy particular labour market outcomes than others, it is therefore axiomatic that differences in the composition of a region's population will partly determine the distribution of its population across different labour market states. This is the so-called composition or characteristic effect. Structural effects, on the other hand, measure the extent to which otherwise identical individuals gravitate towards particular labour market outcomes. 
Where structural effects are found to be an important factor in accounting for differences in labour market outcomes between regions, it is likely that they will in part be due to differences in demand between the regions. Demand-based explanations of structural effects however, are not the only possible explanation, as they can also arise as a result of differences in preferences and/or cultural factors that have a specific regional dimension. Although these latter effects are likely to be small, they cannot be entirely ignored. As a result, the contribution made by structural effects should be considered as providing a measure of the upper bound to the part played by demand side influences in accounting for regional differences in labour market outcomes.

The purpose of the present paper is to use the preceding conceptual approach to analyse regional differences in labour market performance across each of the 11 standard regions of Great Britain. An important novelty of the approach is that whereas previous studies have focused on either unemployment or employment rates, the analysis here is undertaken using a unified empirical framework that explicitly incorporates three labour market states: namely employment, unemployment and economic inactivity. Regional differences in each of these outcomes are then considered within a decomposition framework that distinguishes between differences that are attributable to a composition effect on the one hand and a structural effect on the other. To our knowledge this is the first time such an analysis has been undertaken for the UK. The analysis is also important in the context of the sorts of policy reforms proposed in the recently published Five Year Strategy, which among other issues, highlights the need to assist those on incapacity benefit to (return to) work. Part of our 
analysis focuses on the key role of ill health in determining labour market outcomes and hence regional labour market performance.

The remaining parts of the paper are set out as follows. Section II provides a brief discussion of the theoretical background relating to the existence of regional inequalities in labour market performance. Section III outlines the empirical methodology used, with the results discussed in section IV. Finally, conclusions and policy implications are provided in section $\mathrm{V}$.

\section{Theoretical Background}

Orthodox theory implies that labour markets adjust quickly to eliminate spatial differences either in excess labour supply or in wages. The adjustment mechanism assumed is a simple one: specifically, wage flexibility ensures market clearing, while firm and/or worker mobility equalises spatial differences in wages. Within a fully integrated national economy therefore, region-specific demand or supply shocks produce only temporary disturbances, and in the long run regional employment rates, participation rates, unemployment rates and wage rates all converge.

There is however, ample evidence to suggest that regional economies do not converge in the way implied by orthodox theory. Krugman $(1991,1993)$ for example, explains why some regions are not only more sensitive to demand or technological shocks than others, but also why such shocks can have a permanent affect on a region's long-run growth path. According to Krugman, trade and external economies lead to increasing returns to scale and concentration, which in turn produce more specialised regions. Externalities arise as a result of access to specialized labour, the availability of 
specialist supplier chains, and the presence of technological spillovers, and once established, these lock-in and propagate the advantages of regional specialisation. As a result, regions become more sensitive to either demand or technology shocks that make region-specific recessions much more likely.

Latterly, Martin and Tyler (2000) have suggested that Krugman's approach is similar to the standard 'cumulative causation' model of regional development. According to this model, successful regions enjoy a cumulative and self-reinforcing advantage over less successful regions. The concentration of workers and firms in regions creates positive externalities that are self-reinforcing and cumulative, and result in localised endogenous growth. Regions subjected to adverse structural demand shocks therefore, are less likely to recover; while relative factor prices may be able to fall in such regions, they are unlikely to be able to fall far enough to offset the cumulative advantage enjoyed by more successful regions.

The collapse of traditional heavy industries and mining that took place in the UK during the 1980s and 1990s seems to provide a good fit for this regional specialization hypothesis. These industries were spatially concentrated in areas such as the North of England and Wales, and it is probably not a coincidence that a map of regional inequality in Great Britain identifies many of these areas as being problematic today. Part of the problem faced by these regions is that neither of the adjustment mechanisms assumed in the orthodox model seems to operate to the same extent in the UK and Europe as they do in the US. Labour mobility for example, is lower in the UK than the US, while wages are not as flexible either because of institutional wage setting arrangements or because a wage floor is created by 'overly generous' state 
benefits. As a result, sector- or region-specific demand shocks in the UK have led to job losses and increases in non-employment, which have tended to persist as neither labour mobility nor relative wage movements have been able to restore equilibrium.

Bailey and Turok (2000) have shown that adjusting to job losses in Britain's major cities has been especially problematic for some low-income groups. Although adjustments through migration and commuting did occur for some high-income groups, among many low paid manual workers such adjustments were much less important. Often, high housing and relocation costs prevent many low-income groups from migrating to more prosperous regions, while poor mobility and high travel costs similarly restrict commuting possibilities for this group. Bailey and Turok (2000) also find that labour mobility is significantly weaker among low-income women than among low-income men, and that job losses can lead to significant increases in reported levels of economic inactivity for some groups of displaced workers. For example, they calculate that 1,000 job losses in Britain's largest cities will lead to an increase in economic inactivity of 124 for men, whereas the comparable figure for women for 1,000 job losses is 453 .

There is now a substantial body of evidence to suggest that adjusting to large-scale job losses has permanently scarred some regions in the UK, particularly those most seriously affected by the job losses that occurred in the heavy industry and mining sectors during the 1980s and 1990s. While job losses in these regions have been partly offset by migration and commuting, this has not been sufficient to remove all the excess labour supply that was created by the decline of these industries. However, only part of the resulting increase in excess labour supply has been absorbed into 
unemployment, the rest has been accounted for by falling participation rates particularly among older and less skilled men (see Beatty and Fothergill, 1996, 2002, and Turok and Edge, 1999).

In Britain it is increasingly being recognised that the boundary between economic activity and inactivity is becoming much more blurred (Bryson and Mackay, 1994). Schweitzer (2003) for example, has shown that a significant number of the economically inactive have propensities to work that are equal to those of the unemployed. This suggests that current measures of unemployment, particularly those based on the claimant count, may significantly underestimate the true extent of excess labour supply in Britain's regions. Consequently, unemployment may be partly hidden among those individuals currently classified as being economically inactive.

There is a now a growing awareness that conventional measures of unemployment may not only underestimate the level, but also the extent of regional variations in the number of individuals without work. Dorling and Woodward (1995) for example, have shown that the spatial concentration of working age adults without work, but not unemployed, accounts for a significant proportion of the economic polarization that occurred in British society during the 1980s. Similarly Gregg et al. (1999) have shown that the proportion of households containing no adults in work rose from 4 per cent in 1968 to 17 per cent in 1996, and that workless households, where poverty rates are highest, tend to be spatially concentrated in areas where employment rates are low.

Fothergill (2001) has argued that men and women whose joblessness is counted as 'sickness' rather than 'unemployment' is one of the most important sources of hidden 
unemployment in the UK today. Similarly Beatty et al. (2000) document the substantial rise in the number of individuals claiming sickness-related benefits in the UK between 1981 and 1998, when the numbers increased from 0.6 million to 1.9 million. Such dramatic increases in sickness are not easy to explain when placed against the background of generally improving health standards. However, the geographical distribution of sickness claimants does coincide with the older industrial areas of Northern England, South Wales and Scotland, which were the areas most seriously affected by the large job losses that took place in the UK during the 1980s and 1990s as a result of industrial restructuring.

Beatty et al. (2000) offer the following explanation for the relationship that seems to exist between employment, recorded unemployment, and recorded sickness in the UK. The process starts with the need to make job cuts, which fall disproportionately on the low skilled and those with 'health' problems. Given that sickness-related benefits in the UK are more generous than unemployment benefits, it is hardly surprising that workers with health problems choose to move into economic inactivity rather than unemployment when their jobs are lost. Similarly, where job losses occur in regions dominated by heavy industries, which are known to be damaging to the health of their workers, it is likely that proportionally more displaced workers will be eligible to claim sickness-related benefits. Finally, the tendency for displaced workers with poor health to choose economic inactivity rather than unemployment is reinforced in regions where the labour market is slack because people with poor health know that they are likely to be at the back of a long queue for jobs. 
In the Beatty et al. model, even when employment opportunities start to improve, those on sickness related benefit still tend to remain economically inactive because they are unable to advance up the job queue. Thus while recorded unemployment can fall and participation rates for women increase in these areas, sickness counts remain largely unaffected. As Fothergill (2001) points out there is nothing fraudulent in the behaviour of these people: most are likely to have a genuine health problem, even though it may not be fully incapacitating. In a fully employed economy however, they could reasonably be expected to be in work.

The model just described seems to fit the facts for the UK, both in terms of where the major job losses were concentrated in the 1980s and 1990s and the resulting patterns of sickness that were then revealed. When labour markets do not operate effectively, perverse demand shocks that result in regionally concentrated job losses are likely to cause long-lasting problems for some regions. Consequently, an individual's chance of finding work is not affected solely by who they are, but also where they live; a finding that would appear to put regional policy firmly back onto the policy agenda in Britain.

\section{Empirical Methodology}

Individuals are assumed to choose the labour market state that offers them the highest return or reward. Assuming that the return or reward to different choices is given by:

$$
\mathrm{R}_{\mathrm{ij}}=\mathrm{X}_{\mathrm{i}} \beta_{\mathrm{j}}+\varepsilon_{\mathrm{ij}}\left\{\begin{array}{l}
\mathrm{i}=1,2,3, \ldots \mathrm{n} \\
\mathrm{j}=1,2,3, \ldots \mathrm{m}
\end{array}\right.
$$


where $X_{i}$ is a vector of characteristics determining the size of the return/reward index for the $\mathrm{j}^{\text {th }}$ choice, $\mathrm{R}_{\mathrm{ij}}$, for the $\mathrm{i}^{\text {th }}$ individual; $\beta_{\mathrm{j}}$ is a vector of conformable parameters; and $\varepsilon_{\mathrm{ij}}$ is a random disturbance term. Then, if $\mathrm{Y}_{\mathrm{i}}$ is a polychotomous variable indicating the labour market status of an individual, the individual will choose that labour market state for which:

$\mathrm{Y}_{\mathrm{i}}=\mathrm{j}$ if $\mathrm{R}_{\mathrm{ij}}>\mathrm{R}_{\text {is }} \forall \mathrm{s} \neq \mathrm{j}$

Maddala (1983) has shown that under appropriate distributional assumptions a multinomial logit model can be used to represent the choices described by $\mathrm{Y}_{\mathrm{i}}$, namely:

$$
\operatorname{Prob}\left(Y_{i}=j\right)=\frac{\exp ^{X_{i} \beta_{j}}}{\sum_{j=1}^{m} \exp ^{x_{i} \beta_{j}}}\left\{\begin{array}{l}
i=1,2,3, \ldots n \\
j=1,2,3, \ldots m
\end{array}\right.
$$

where equation (3) indicates the probability of the ith individual choosing the jth choice given a set of characteristics represented by $X_{i}$.

Estimates of (3) allow differences in the proportion of the working age population found in different labour market states in one region to be compared to those found in the rest of Great Britain using a decomposition framework suggested by Neumark (1988) and Oaxaca and Ramsom (1994). The procedure used can be explained as follows. First, the difference in the incidence of the $\mathrm{j}^{\text {th }}$ labour market outcome between region $r$ and the Rest of Great Britain ( $R$ ) is equal to (see Gomulka and Stern, 1990): 
$\overline{\mathrm{I}}_{j}^{\mathrm{r}}-\overline{\mathrm{I}}_{\mathrm{j}}^{\mathrm{R}}=\overline{\mathrm{P}}_{\mathrm{j}}^{\mathrm{r}}\left(\mathrm{X}_{\mathrm{i}}^{\mathrm{r}} \hat{\beta}^{\mathrm{r}}\right)-\overline{\mathrm{P}}_{\mathrm{j}}^{\mathrm{R}}\left(\mathrm{X}_{\mathrm{i}}^{\mathrm{R}} \hat{\beta}^{\mathrm{R}}\right) \quad$ for $\mathrm{j}=1,2,3, \ldots \mathrm{m}$

where $\overline{\mathrm{I}}_{\mathrm{j}}^{\mathrm{r}}=\frac{1}{\mathrm{n}^{\mathrm{r}}} \sum_{\mathrm{i}} \mathrm{P}_{j}^{\mathrm{r}}\left(\mathrm{X}_{\mathrm{i}}^{\mathrm{r}} \hat{\beta}^{\mathrm{r}}\right)=\overline{\mathrm{P}}_{\mathrm{j}}^{\mathrm{r}}\left(\mathrm{X}_{\mathrm{i}}^{\mathrm{r}} \hat{\beta}^{\mathrm{r}}\right) ; \quad \overline{\mathrm{I}}_{\mathrm{j}}^{\mathrm{R}}=\frac{1}{\mathrm{~N}^{\mathrm{R}}} \sum_{\mathrm{i}} \mathrm{P}_{j}^{\mathrm{R}}\left(\mathrm{X}_{\mathrm{i}}^{\mathrm{R}} \hat{\beta}^{\mathrm{R}}\right)=\overline{\mathrm{P}}_{\mathrm{j}}^{\mathrm{R}}\left(\mathrm{X}_{\mathrm{i}}^{\mathrm{R}} \hat{\beta}^{\mathrm{R}}\right) ;$ $\overline{\mathrm{I}}_{\mathrm{j}}^{\mathrm{r}}$ is the incidence of labour market status $\mathrm{j}$ in the rth region; $\overline{\mathrm{I}}_{\mathrm{j}}^{\mathrm{R}}$ is the incidence of the labour market status $\mathrm{j}$ in the Rest of Great Britain; $\mathrm{P}_{\mathrm{j}}^{\mathrm{r}}($.$) is an estimate of the$ probability that the $\mathrm{i}^{\text {th }}$ individual in the $\mathrm{r}^{\text {th }}$ region has labour market status $\mathrm{j} ; \overline{\mathrm{P}}_{\mathrm{j}}^{\mathrm{r}}($.$) is an$ average of $\mathrm{P}_{j}^{r}($.$) for the \mathrm{r}^{\text {th }}$ region; $\mathrm{P}_{j}^{\mathrm{R}}($.$) and \overline{\mathrm{P}}_{\mathrm{j}}^{\mathrm{R}}($.$) are similarly defined for the Rest$ of Great Britain; $\hat{\beta}^{\mathrm{r}}$ and $\hat{\beta}^{\mathrm{R}}$ are estimates of equation (3) for the $\mathrm{r}^{\text {th }}$ region and the Rest of Great Britain respectively; and $\mathrm{n}^{\mathrm{r}}$ and $\mathrm{N}^{\mathrm{R}}$ are the number of individuals in the $\mathrm{r}^{\text {th }}$ region and the Rest of Great Britain respectively.

Second, differences in the incidence of labour market outcomes shown in (4) can be shown to be equivalent to:

$\overline{\mathrm{I}}_{j}^{\mathrm{r}}-\overline{\mathrm{I}}_{\mathrm{j}}^{\mathrm{R}}=\left(\begin{array}{l}{\left[\overline{\mathrm{P}}_{\mathrm{j}}^{\mathrm{r}}\left(\mathrm{X}_{\mathrm{i}}^{\mathrm{r}} \hat{\beta}^{*}\right)-\overline{\mathrm{P}}_{\mathrm{j}}^{\mathrm{R}}\left(\mathrm{X}_{\mathrm{i}}^{\mathrm{R}} \hat{\beta}^{*}\right)\right]+} \\ \left\{\left[\overline{\mathrm{P}}_{\mathrm{j}}^{\mathrm{r}}\left(\mathrm{X}_{\mathrm{i}}^{\mathrm{r}} \hat{\beta}^{\mathrm{r}}\right)-\overline{\mathrm{P}}_{\mathrm{j}}^{\mathrm{r}}\left(\mathrm{X}_{\mathrm{i}}^{\mathrm{r}} \hat{\beta}^{*}\right)\right]+\left[\overline{\mathrm{P}}_{\mathrm{j}}^{\mathrm{R}}\left(\mathrm{X}_{\mathrm{i}}^{\mathrm{R}} \hat{\beta}^{*}\right)-\overline{\mathrm{P}}_{\mathrm{j}}^{\mathrm{R}}\left(\mathrm{X}_{\mathrm{i}}^{\mathrm{R}} \hat{\beta}^{\mathrm{R}}\right)\right]\right\}\end{array}\right)$ for $\mathrm{j}=1, \ldots, \mathrm{m}(5)$

where following Neumark (1988) and Oaxaca and Ransom (1994), $\hat{\beta}^{*}$ represents the baseline structure on which the decomposition reported in (5) is based. In practice $\hat{\beta}^{*}$ is found by estimating equation (3) for all individuals in Great Britain, and can be interpreted as representing a hypothetical case in which the structure governing labour market outcomes in each region is the same. 
In the decomposition shown in (5), the first term, $\left[\bar{P}_{j}^{r}\left(X_{i}^{r} \hat{\beta}^{*}\right)-\bar{P}_{j}^{R}\left(X_{i}^{R} \hat{\beta}^{*}\right)\right]$, represents the part of any difference in the incidence of labour market outcome $\mathrm{j}$ between region $r$ and the Rest of Great Britain that can be attributed to differences in the composition of the two populations. The second term in braces, on the other hand, is the part of any regional difference in the incidence of particular labour market states that can be attributed to differences in the underlying structure (coefficients) determining outcomes in the two areas ${ }^{3}$. As this structural effect reflects differences in regional propensities towards particular labour market states shown by otherwise identical individuals, they will, as noted above, large be due to differences in demandside influences and/or differences in cultural attitudes and preferences that have a specific regional dimension.

As the multinomial logit model described by equation (3) is a non-linear probability model, it is not possible to unpack the contribution made by individual characteristics to the composition effect using standard procedures adopted elsewhere in the decomposition literature. However, Even and Macpherson (1993) have proposed a method for decomposing the composition effect in a non-linear probability model. Their method, which we use here, identifies the contribution made by the $k^{\text {th }}$ characteristic to the difference in labour market status as:

$$
C_{j k}=\left[\bar{P}_{j}^{r}\left(X_{i}^{r} \hat{\beta}^{*}\right)-\bar{P}_{j}^{N_{r}}\left(X_{i}^{R} \hat{\beta}^{*}\right)\right]\left[\frac{\left(\bar{X}_{k}^{r}-\bar{X}_{k}^{R}\right) \hat{\beta}_{j k}^{*}}{\left(\bar{X}^{r}-\bar{X}^{R}\right) \hat{\beta}_{j}^{*}}\right] \quad \text { for } j=1,2,3, \ldots, m
$$

where $C_{j k}$ is the portion of the overall composition effect attributed to the $k^{\text {th }}$ characteristic, and is determined by that characteristic's share of the difference in

\footnotetext{
${ }^{3}$ Although the coefficients associated with one of the choices is normalized to zero in the estimation, the results for this group can be recovered from the adding up restriction given by $\sum\left(\overline{\mathrm{I}}_{j}^{\prime}-\overline{\mathrm{I}}_{j}^{\mathrm{R}}\right)=0$, which

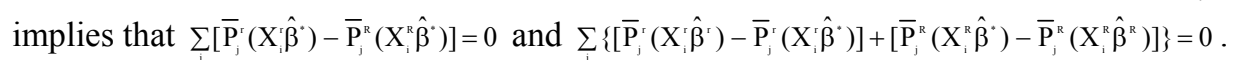


labour market status propensity, when evaluated at the at the means of the data and the baseline structure represented by $\hat{\beta}_{\mathrm{j}}^{*}$.

\section{Data and Results}

The data used in the analysis are taken from the Quarterly Labour Force Survey (QLFS). The QLFS interviews approximately 60,000 respondents each quarter and has a rotating panel design, in which each individual in the sample is interviewed on 5 separate occasions during the course of a year. To ensure that no individual enters the data more than once, individuals are only included in our sample if it is their first interview. In order to obtain reasonable sample sizes in each of the regions considered in the analysis, the data used are pooled from the first quarter of 1997 to the last quarter of 2000. This pooling of the data also permits the analysis to be undertaken separately for both males and females. The sample is restricted to individuals of working age, and excludes all students who, because of their unique status, tend to be only temporarily detached from the labour market. In total the sample consists of 302,170 individuals of whom 152,733 are male and 149,437 female.

Table 1 shows the incidence of employment, unemployment, and economic inactivity in each of the 11 standard regions of Great Britain used in the analysis ${ }^{4}$. Figures are reported separately for men and women, and show that the gender pattern of labour market outcomes is quantitatively similar in all standard regions. Thus, the incidence of employment and unemployment is higher for men than for women, while the reverse is true for economic inactivity rates: in Great Britain as a whole, for example, the employment rate is 81 percent for men and 70 per cent for women, while the

\footnotetext{
${ }^{4}$ Unemployment is defined using the ILO definition.
} 
economic inactivity rate for men is only 14 percent compared to 26 percent for women.

Although Table 1 indicates that regions exhibit similar patterns of labour market outcomes when men are compared to women, nonetheless there are also significant differences between regions. Some regions are clearly more successful than others and they tend to have higher employment rates, lower unemployment rates, and lower inactivity rates than less successful regions ${ }^{5}$. For example, male employment rates are highest in the South East (87 percent), South West (85 percent) and East Anglia (85 percent) and lowest in Northern England (73 percent), Wales (75 percent), the North West (78 percent) and Scotland (78 percent).

As regional unemployment rates converged in the mid- to late-1990s (see Bradley and Taylor, 1994), it is hardly surprising that the data in Table 1 reflect this trend. Consequently, the difference between the region with the highest unemployment incidence and the region with the lowest unemployment incidence is only 4 percentage points for men and 2 percentage points for women. Significantly larger differences, however, are found in regional employment and inactivity rates for both men and women. For example, among men (women) there is a 14 (9) percentage point difference between the region with the highest and lowest employment rates, while the corresponding difference in economic inactivity rates is $10(9)$ percentage points.

Of course the pronounced differences in regional employment and inactivity rates shown in Table 1 could simply be due to a composition effect - the so-called

\footnotetext{
${ }^{5}$ From this point on we will use the term unemployment rate to refer to unemployment incidence, where the denominator used to define the rate is the working age population net of students.
} 
characteristics hypothesis (Green, 1997). It is well known, for example, that certain individuals are more likely to occupy particular labour market states than others. Thus, older people are less likely be economically active than the young; people with qualifications are more likely to be in employment than people with no qualifications; and married women with children are more likely to be economically inactive than single or married women with no children. It follows therefore, that if a region has a higher concentration of individuals who are more likely to occupy a particular labour market state, say economic inactivity, then that region is more likely to have a higher inactivity rate.

Evidence to support the characteristics hypothesis is provided by the table of means reported in Table 2. For example, relative to their overall share of the total population, men aged 56+ in Great Britain are disproportionately more likely to be economically inactive than either younger or prime age men. Similarly, men or women with qualifications are more likely to be employed than men and women with no qualifications. The table also highlights the importance of long-term illness in describing the characteristics of the economically inactive. Thus whereas the proportion of men (women) reporting a long-term illness in the combined sample is only 17 (16) percent, among the economically inactive the proportion rises dramatically to 68 (36) percent.

Those reporting a long-term health problem form an important part of the analysis conducted in this paper; as noted above, assisting those on incapacity benefits into work is a major focus of the Government's policy strategy. However, as differences in the incidence of ill health both between regions and across different labour market 
states are likely to reflect demand as well as supply-side influences, we test the sensitivity of the results reported below to the inclusion of a (self-reported) long-term, ill health variable ${ }^{6}$. The set of results labeled 'Specification 1' below excludes a measure of ill health, while those labeled 'Specification 2' include an ill health measure.

\section{Multinomial Logit Estimates of Labour Market Status Model: Specification 1}

Multinomial logit estimates of equation (3), along with associated p-values, are reported for employment and economic inactivity in Table 3.1 for men and Table 3.2 for women ${ }^{7}$. These estimates are for Great Britain as a whole but qualitatively similar findings are found in each of the separate regions. Marginal probabilities are also shown for each of three labour market outcomes identified in the analysis: namely employment, economic inactivity, and unemployment. The marginal effects reported in Tables 3.1 and 3.2 are all measured relative to the same baseline individual who is married, white, a non-head of household, an owner-occupier, with no children or qualifications, and aged 31-35 years of age. Thus a man (woman) with a degree (i.e., hquall=1) is 4.9 (11.0) percent more likely to be employed than the baseline individual with no qualifications, and $3(10.2)$ percent and $1.9(0.8)$ percent less likely to be either economically inactive or unemployed respectively.

\footnotetext{
${ }^{6}$ Of course ill health is not unique in this respect. Older workers, for example, might also find themselves at the back of job queues in less tight labour markets. However, the effect is likely to be greatest for those reporting ill health for two reasons. First, because individuals in poor health were felt to be more difficult to place back into work, many were encouraged by the Employment Service in the 1980s and early-to-mid 1990s to claim invalidity benefit rather than unemployment benefit (Nickell and Quintini, 2001, and National Audit Office, 1989). Second, the design of the social security system provides an incentive to workers to seek out the more generous and less tightly monitored sicknessrelated benefits whenever they are displaced from employment (Lindbeck, 1995, and Nickell and Van Ours 2000).

${ }^{7}$ The coefficients for unemployment were normalized to zero in the multinomial logit procedure for both men and women.
} 
The influence that specific variables have on the likelihood of an individual occupying different labour market states, as reported in Tables 3.1 and 3.2, are largely in line with prior expectations. For example, older men and women are much less likely to be in employment and much more likely to be economically inactive than prime aged individuals. Age related effects are stronger for those aged over 50 and are particularly pronounced among those aged 56 or more. Hence a man (woman) aged 51-55 is 8.5 (16.7) percent less likely to be in employment and 8.3 (17.2) per cent more likely to be economically inactive than the baseline individual aged between 31 35 years, while a man (woman) aged 56 or more is 26.5 (30.2) percent less likely to be in employment and 26.4 (31.1) percent more likely to be economically inactive.

As noted earlier, educational qualifications significantly increase an individual's chance of being in employment. In fact, individuals with qualifications are not only more likely to be in employment, but also less likely to be economically inactive or unemployed than individuals with no qualifications. Interestingly Tables 3.1 and 3.2 also show that the effect education has on labour market status is typically graduated for both men and women, i.e. the higher the qualification level, the more likely the individual is to be in employment and the less likely they are to be either economically inactive or unemployed. However, education effects tend to be quantitatively larger for females than for males, at least in terms of the effect that education has on the likelihood of an individual being either employed or economically inactive. Thus, compared to a man with no qualifications, a man with A-levels is 3.8 percent more likely to be in employment and 2.3 and 1.5 percent less likely to be economically inactive or unemployed respectively. A woman with Alevels on the other hand, is 8.7 per cent more likely to be in employment than woman 
with no qualifications, and 8.0 and 0.7 percent less likely to be either economically inactive or unemployed.

Individuals with formal qualifications are more much likely to be attached to the labour market than individuals without qualifications, and the reasons for this are not hard to understand. First, market opportunities are likely to be better for individuals with qualifications, particularly as employers increasingly look for more skilled and able workers. HM Treasury and the Department for Work and Pensions (2001), for example, has recently noted that economic inactivity rates have risen for people with no qualifications, and that this can be largely attributed to a downward shift in demand for low skilled workers. Second, and no less importantly, the incentive to participate in the labour market is likely to be higher for individuals with qualifications as they seek to gain a return to investment they have made in education.

Tables 3.1 and 3.2 also show that the type of housing that a man or woman occupies affects their labour market status in similar ways. Specifically, men and women in subsidized council housing are much less likely to be in employment and more likely to be either economically inactive or unemployed than individuals in other types of housing tenures. For instance men (women) living in subsidized council housing are 27.9 (27.2) percent less likely to be in employment, 17.4 (22.9) percent more likely to be economically inactive, and 10.5 (4.3) percent more likely to be unemployed than owner-occupiers. These results are broadly in line with those found elsewhere by Nickell (1980) and Hughes and McCormick (1985, 1987). Even though the focus of these earlier studies was on unemployment, nevertheless the arguments used can still be generalized to the analysis of other labour market outcomes. Gregg (2002), for 
instance, has suggested three reasons why the occupation of social housing may reduce employment probabilities and increase the likelihood of non-employment: specifically (a) reduced residential mobility; (b) neighbourhood effects that include poorer social networks; and (c) 'residualization' effects based on the residency of individuals in peripheral locations. Each acts as a competitive disadvantage that reduces an individual's chance of being employed and increases their chance of being either unemployed or economically inactive.

Many of the factors determining the labour market status of men and women are similar, even though the magnitude of specific responses do differ between the two groups. One important exception to this general rule however, concerns household composition, and in particular the influence that children have on the labour market status of men and women. Specifically, women with dependent or pre-school aged children are less likely to be in employment and more likely to be economically inactive than men, for whom family composition effects are much less prominent. Among women, the probability of being in employment declines incrementally with the number of dependent children, from being 5.1 percent less likely to be in employment with one dependent child to 18.8 percent less likely to be in employment with 3 or more dependent children. Interestingly, the effect that the presence of preschool children has on women's labour market status is even more striking. For example, a woman with a pre-school child is 23.5 percent less likely to be in employment and 23.6 percent more likely to be economically inactive than an otherwise comparable woman. An explanation for these results is not hard to find, and is likely to be due to the fact that women still retain the primary responsibility for childcare arrangements in most households. Consequently, where the costs of 
childcare are high relative to what a woman with young children can normally expect to earn, women are less likely to work and are more likely to be classified as economically inactive.

\section{Decomposition Results for Specification 1}

The results of the decomposition analysis outlined in section II are reported in Tables 4.1 and 4.2 for men, and Tables 5.1 and 5.2 for women. Tables 4.1 and 5.1, for example, show the share of any employment, unemployment, or economic inactivity rate difference that can be attributed to either a composition effect on the one hand or a structural effect on the other. Tables 4.2 and 5.2 then disaggregate any composition component into its constituent parts using the procedure described by equation (6).

The main features of the tables can be summarized as follows. First, as noted earlier, regional differences in labour market outcomes are most marked in employment and economic inactivity rates. Compared to the rest of Great Britain for example, regions with the lowest employment rates are Northern (8.5 percent below the rest of GB), Wales (6.9 percent below the rest of GB), North West (4.1 percent below the rest of GB), and Scotland (3.8 percent below the rest of GB) for males; and Northern (5.0 percent below the rest of GB) and Wales (4.7 percent below the rest of GB) for females. Regions with better employment rates than the rest of Great Britain, on the other hand, are the South East (7.4 percent above the rest of GB), East Anglia (4.1 percent above the rest of GB), and the South West (4.1 percent above the rest of GB) for males; and the South West (5.1 percent above the rest of GB) and South East (4.5 percent above the rest of GB) for females. As might be expected, a similar pattern of regional advantage, or disadvantage, is also indicated by differences in regional 
economic inactivity rates. Hence regions with relatively high employment rates have relatively low economic inactivity rate; and regions with relatively low employment rates have relatively high economic inactivity rates. In fact, as regional unemployment rate differences are typically small, there is an almost symmetrical relationship between a region's relative employment performance and its performance measured in terms of economic inactivity. In light of this finding we decided to concentrate the discussion of differences in regional labour market outcomes reported below to those pertaining to employment and economic inactivity rate differences, and as a result the much smaller differences in regional unemployment rates are largely ignored.

The decomposition analysis reported in Tables 4.1 and 5.1 shows that the relative contribution made by composition and structural effects to explaining differences in labour market outcomes across each of the 11 standard regions analyzed varies from region to region. However, a distinctive pattern does still emerge from these results. In particular, structural effects tend to be more important in less successful regions and less important in more successful regions. For example, for men (women) living in the Northern region around 80 (71) percent of the male (female) employment rate disadvantage is accounted for by structural differences, while around 77 (70) percent of the Northern region's higher economic inactivity rate for men (women) is also due to structural effects. Similar findings for males are also found for the Northern and Yorkshire and Humberside regions. For men (women) living in the South East on the other hand, the structural component accounts for only 59 (21) percent of the region's employment advantage, and 59 (15) percent of the region's lower economic inactivity rate. Although structural effects clearly play a part in explaining differences in labour market outcomes in all regions, the fact that they are larger in the poorer performing 
regions does lend support to the idea that these regions are most likely to be affected by demand-side problems.

Tables 4.2 and 5.2 also indicate that while the contribution individual characteristics make to the composition effect is not the same in each region, some factors are clearly more important than others. Thus housing tenure, age, qualifications and ethnicity are typically identified as being some of the most important factors, but they do not always operate in the same way in all regions. This can be most clearly illustrated by considering two regions, the South East and Wales, which have markedly different out-turns in terms of the measures of labour market performance considered in this analysis.

The South East is a more successful region. It has a higher incidence of employment and a lower incidence of economic inactivity than the Rest of Great Britain. Tables 4.2 and 5.2 show that the South East has a less favourable age structure than the rest of Great Britain, but a more favourable structure in terms of qualifications and housing tenure. For example, if the South East had the same age structure as the rest of Great Britain, and the determinants of labour market status were the same in all regions, then both the male (female) employment and inactivity rate advantage in the South East would be around 4 (8) percent higher. Similarly, if males living in the South East had the same level of qualifications as in the rest of Great Britain the male (female) employment rate advantage in the South East would be 11 (35) percent lower, while the male (female) inactivity rate advantage would be reduced by 11 (38) percent. Interestingly, the contribution made by housing tenure is even more pronounced in the South East than either qualifications or age, which partly reflects 
the area's greater economic prosperity which has resulted in a higher incidence of owner occupancy and a lower incidence of council housing occupancy than in the rest of Great Britain.

Compared to the South East, Wales is a much less successful region. It has a lower employment rate and a higher inactivity rate than the Rest of Great Britain. Tables 4.2 and 5.2 reveal that compared to the Rest of Great Britain, Wales is relatively disadvantaged in terms of its population's age, qualifications, and housing tenure. Thus if men (women) living in Wales had the same age structure as the Rest of Great Britain, its overall employment disadvantage would be 7 (9) percent lower, and its inactivity disadvantage would be 9 (10) percent lower. Not surprisingly, Wales has a relative 'advantage' in terms of having relatively fewer ethnic minorities, who are typically less likely to be employed and more likely to be either unemployed or economically inactive than the white majority.

\section{Multinomial Logit Estimates of Labour Market Status Model: Specification 2}

To examine the effect that health problems have on an individual's labour market status, specification 2 adds a self-reported ill-health variable to the variables already included in specification 1 . As qualitatively similar results are found when estimating equation (3) for those variables common to both specifications 1 and 2, there is little point in repeating the discussion already reported above ${ }^{8}$. Instead, we focus attention on the effect that ill health has in determining an individual's labour market status, and in this regard three features of the results are worth highlighting.

\footnotetext{
${ }^{8}$ Levels of significance are similar but the sizes of calculated marginal effects are typically reduced.
} 
First, as expected, estimates of equation (3) show that ill health reduces an individual's chance of being employed and increases their chance of being either economically inactive or unemployed. Second, ill health has a quantitatively larger effect on employment and economic inactivity propensities than on unemployment, and the magnitude of the effect is larger for females than for males. Third, and finally, although the nature of the results discussed so far hold for all regions, there are nevertheless important regional differences in the impact that ill health has in different regions, and it is to these that we now turn.

The marginal effects reported in Table 6 show that the influence that ill health has on employment and economic inactivity propensities tends to be larger in underperforming regions than in more prosperous regions where employment rates are higher and inactivity rates are lower. Thus, compared to a male (female) in 'good' health, a male (female) with a self-reported, long-term ill health problem is 40 (48) percent less likely to be in employment in Wales, 31 (37) percent less likely to be in employment in the Northern region, and 25 (39) percent less likely to be in employment in the North West. The equivalent employment disadvantage for a male (female) with a health problem in the South East, South West and East Anglia, on the other hand, is only 3 (23) percent, 15 (22) percent and 15 (25) percent respectively. Similarly a male (female) with a self-reported health problem is 37 (47) percent more likely to be economically inactivity in Wales, 29 (36) percent more likely to be economically inactive in the Northern region, and 21 (39) percent more likely to be economically inactive in the North West; while the corresponding figures for a male (female) living in the South East, South West and East Anglia are significantly 
smaller and estimated to be only 11 (22) percent, 13 (20) percent and 9 (20) percent respectively.

Since the effect that ill health has on labour market status is most pronounced in those areas that were, by common consent, most exposed to the effects of industrial restructuring in the 1980s and 1990s, these results seem to offer some support to the Beatty et al. (2000) model outlined earlier. However, the role played by ill health in this analysis is not merely confined to the effect it has on the likelihood of an individual being employed or economically inactive. Instead, important differences also emerge in terms of the incidence of reported ill health across regions.

Table 7 shows the incidence of self-reported ill health in each of the 11 standard regions considered in the analysis. Separate figures are reported for men and women, but a familiar pattern emerges for both. Specifically, there is a higher incidence of reported ill health in the least successful 'Northern' regions and a lower incidence of ill health in the more successful and prosperous 'Southern' regions. For example, the incidence of reported ill health is highest in North and Wales and lowest in the South East, London, South West and East Anglia. Of course, how much of any reported ill health is a legacy of a region's industrial structure and how much is the result of the advice that (some commentators claim) was given to workers losing their jobs as a result of industrial restructuring in the 1980 s and 1990s to claim sickness related benefits rather than unemployment benefit is a moot point. What cannot be denied, however, is that the incidence of reported ill health is not only higher in some regions than others, but that in those regions where the incidence of ill health is highest, 
having a health problem means that an individual is much less likely to be in employment and much more likely to be economically inactive than elsewhere.

\section{Decomposition Results for Specification 2}

The results of the decomposition analysis including the health variable are reported separately for men and women in Tables 8.1 and 9.1. The layout of the tables is the same as that used earlier in Tables 4.1 and 5.1. For each of the labour market outcomes considered therefore, they show how much of any regional difference is attributable to either a composition effect or a structural effect. Similarly, as in Tables 4.2 and 5.2, the composition effect is broken down into its constituent parts for men and women in Tables 8.2 and 9.2.

Tables 8.1 and 9.1 indicate that including a health variable in the analysis has a dramatic effect on the decomposition results ${ }^{9}$. Specifically, its inclusion increases the importance of composition effects in accounting for inter-regional differences in both employment and economic inactivity rates. However, the effect produced is consistently larger in some of the worst performing regions (i.e. Northern England, Wales and the North West), which typically also have the highest incidences of reported ill health. For example, in Northern England, the part of the male (female) employment disadvantage attributable to a composition effect increases from 20 (29) percent when the ill health variable is excluded (specification 1) to 44 (53) percent when it is included (specification 2).

\footnotetext{
${ }^{9}$ Including an ill health variable has a negligible impact on the unemployment decompositions.
} 
As the higher levels of reported ill health found in under-performing regions are likely to partly reflect demand-side factors, perhaps it is to be expected that including an ill health variable in the analysis results in an increase in the size of the composition effect and a reduction in the size of the structural effect. It is worth noting, however, that even when a health variable is included in the analysis, structural effects continue to be an important source of regional inequality in both employment and economic inactivity rates: particularly for men and women living in under-performing regions.

Tables 8.2 and 9.2 confirm the important part ill health plays in determining the size of the composition effect. Among both the worst and best performing regions, differences in the incidence of reported ill health account for a significant share of the differences identified in inter-regional labour market performance. The exception is the South West, where the effects of ill health are much smaller than those reported elsewhere. More typically, however, in an under-performing regions like Northern England, around 31 (30) percent of the male (female) employment disadvantage is accounted for by a higher reported incidence of ill health. Similarly, almost 39 (34) percent of the inactivity rate disadvantage reported for men (women) in the Northern region can be attributed to its less favourable health structure. Interestingly, even in better performing regions like the South East, the contribution made to the composition effect by ill health is equally important. In these cases, however, it is normally the region's lower incidence of reported ill health that contributes to its better employment rate and lower economic inactivity rate.

The contributions made by other variables to the characteristic component reported for specification 2 are similar to those reported for specification 1, albeit reduced in 
size in most cases. Thus age, housing tenure, qualifications and ethnicity structure, along with ill health, are the key compositional factors affecting relative labour market performance, and they tend to work in much the same way as previously described. As there is little to be gained from repeating this discussion, we instead proceed to our conclusions, and in particular, offering some policy recommendations based on the results of the analysis.

\section{Conclusions}

Using a decomposition framework, the present paper provides an analysis of the role of compositional and structural factors to differences in regional labour market performance. Uniquely, the approach encompasses the distributions of employment, unemployment and economic inactivity. For the worst performing regions, and excluding any measure of ill health, around 70-80 per cent of the difference in employment and inactivity rates compared to other regions is found to be due to structural effects, with the balance due to compositional factors, among the most important of which are age, qualifications, housing tenure and ethnicity. The impact of structural effects is generally reduced to around 60 per cent when an ill health measure is included in the analysis, with this variable typically dominating the compositional contributions in poorly performing regions. Importantly however, substantial structural effects remain even when controlling for ill health, most notably in the more poorly performing regions.

The policy implications of the analysis seem clear, albeit politically sensitive. Faced by the kind of inequalities in labour market performance that have been identified by this analysis, the government can choose between two options. Either it can sit back 
and do nothing, in which case regional differences in employment and inactivity rates are likely to persist and lead eventually to the 'residualization' of under-performing regions, or it can be pro-active and seek to equalise labour market performance across regions. If the government wishes to be pro-active, it must, as a matter of some urgency, seek to implement policies that address two of the most pressing problems faced by under performing regions.

First, under-performing Northern regions appear to be structurally disadvantaged relative to more prosperous Southern regions, as was the case in the 1980s (see Blackaby and Murphy, 1995). The most likely source of this disadvantage is the dramatic decline in employment that took place in these regions during the 1980 s and 1990s, as large numbers of jobs in both heavy industries and manufacturing were lost in a relatively short space of time. As a result of these changes, individuals living in under-performing regions are much less likely to be in employment and much more likely to be economically inactive than otherwise identical individuals living in more successful regions. Second, and no less importantly, under-performing regions tend to have much higher incidences of reported ill health, which are in turn associated with both lower employment propensities and higher inactivity propensities in all regions.

Given these twin problems, if the aim of policy is to improve the labour market performance of under-performing regions, then a policy framework needs to be designed that will successfully address both of these major problem areas. Such a policy should therefore have two essential ingredients. First, effective gateways need to be established that allow individuals with health problems, and particularly those 
on incapacity benefit ${ }^{10}$, to re-engage with the labour market. The New Deal for Disabled People and the Pathways to Work pilots are welcomed first steps in this direction. However, the voluntary nature of the former is likely to limit the effect this programme will have on reducing current levels of economic inactivity in the UK. The Pathways to Work pilots in contrast, which currently require new claimants to attend six Work-Focused interviews during the early period of their claim, do contain a greater element of compulsion, but are limited in their coverage to around 10 per cent of the country and with mandatory adviser contact being limited to new claimants. The announcement in the Five Year Strategy that these pilots are to be rolled out to cover around a third of the country, and the mandatory contact with an adviser extended to those who have been on incapacity benefits for up to three years are therefore also to be welcomed. From a regional perspective, it is significant that all of the 30 local authority districts with the highest rates of incapacity benefit claimants will be covered under this widening of coverage.

However, the second ingredient of the policy framework is that the government needs to recognize that part of the problem faced by under-performing regions is the result of structural, or demand-side, deficits. Consequently, an effective policy should complement the measures described above with a regional policy that is capable of stimulating the demand for labour in the weakest performing regions. After all, there is little point in providing a push into employment for the economically inactive by establishing an employment gateway if there are no suitable jobs for them to fill. The creation of National Assemblies in Wales and Scotland and Regional Development Agencies in England provide an effective administrative framework for implementing

\footnotetext{
${ }^{10}$ Among men claiming to have a long-term illness, a majority received incapacity benefit payments.
} 
such a policy, but if the policy is to succeed, it must be properly resourced. What is needed therefore, is a revitalised regional policy that not only repackages and redirects existing resources, but also provides additional funding to the weakest regions, enabling them to redress the structural deficits that have resulted in their underperformance relative to more successful regions. 


\section{References}

Bailey, N and Turok, I. (2000). 'Adjustments to job loss in Britain's major cities', Regional Studies, 34, pp. 631-653.

Beatty, C. and Fothergill, S. (1996). 'Labour market adjustment in areas of chronic industrial decline: the case of the UK coalfields', Regional Studies, 30, pp. 627-640.

Beatty, C. and Fothergill, S. (2002). 'Hidden unemployment among men: a case study', Regional Studies, 36, pp. 811-823.

Beatty, C., Fothergill, S., and MacMillan, R. (2000). 'The theory of employment, unemployment and sickness', Regional Studies, 34, pp. 617-630.

Blackaby, D. and Murphy, P. (1995). 'Earnings, unemployemt and Britain's northsouth divide: real or imaginary', Oxford Bulletin of Economics and Statistics, 57, pp. 487-512.

Bradley, S. and Taylor, J. (1994). 'Spatial disparities in the impact of the 1990-1992 recession: an analysis of UK counties', Oxford Bulletin of Economics and Statistics, 56, pp. 367-82.

Bryson, A. and McKay, S. (1994). Is it worth working?, PSI, London.

Department for Work and Pensions, (2005). Department for Work and Pensions Five Year Strategy: Opportunity and Security Throughout Life, HMSO, London.

Dorling, D and Woodward, R. (1995). 'Polarization in Britain: a micro-geographical approach', Seminar paper 65, Department of Geography, University of Newcastle.

Erdem, E. and Glyn, A. (2001). 'Job deficits in UK regions', Oxford Bulletin of Economics and Statistics, 63, pp. 737-52.

Even, E. and Macpherson, D. (1993). The decline of private sector unionism and the gender wage gap, Journal of Human Resources, 28, pp. 279-296.

Fothergill, S., (2001). 'The true scale of the regional problem in the UK', Regional Studies, 35, pp. 241-246.

Gomulka, J. and Stern, N. (1990). 'The employment of married women in the United Kingdom 1970-83’, Economica, 57, pp.171-199.

Green, A., (1997). 'Exclusion, unemployment and non-employment', Regional Studies, 31, pp. 505-520.

Gregg, P., (2002). 'Neighbourhood effects: causes and policy responses', CMPO, University of Bristol, Issue 7, June, 3-8. 
Gregg, P., Hansen, K. and Wadsworth, J. (1999). 'The rise of the workless household', in Gregg P. and Wadsworth J. (eds), The state of working Britain, Manchester University Press.

HM Treasury and Department for Work and Pensions, (2001). The changing welfare state: employment opportunities for all, HSMO, London.

HM Treasury, Department of Trade and Industry and Office of the Deputy prime Minister, (2003). A modern regional policy for the United Kingdom, HSMO, London.

Hughes, G. and McCormick, B. (1985). 'Migration intentions in the UK', Economic Journal, 95, pp.113-123.

Hughes, G. and McCormick, B. (1987). 'Housing markets, unemployment and labour market flexibility in the UK', European Economic Review, 31, pp. 615-645.

Krugman, P. (1991). Geography and trade, Leuven: Leuven University Press.

Krugman, P. (1993). 'The lessons of Massachusetts for EMU'. In Adjustement and growth in the European Monetary Union, Torres F. and Giavazzi F. (eds) Cambridge University Press.

Linbeck, A. (1995). 'Hazardous welfare state dynamics', American Economic Review, 85, pp. 9-15.

Maddala, G. (1983). Limited dependent and qualitative variables in econometrics, Cambridge University Press, Cambridge.

Martin, R. and Tyler, P. (2000). 'Regional employment evolutions in the European Union: a preliminary analysis', Regional Studies, 34, pp. 601-616

National Audit Office, (1989). Invalidity benefit: Report by the Controller and Auditor General, HMSO, London

Neumark, D. (1988). 'Employers' discriminatory behaviour and the estimation of wage discrimination', Journal of Human Resources, 23, pp. 279-295.

Nickell, S. (1980). 'A picture of male unemployment in Britain', Economic Journal, 90, pp. 776-794.

Nickell, S. and Quintini, G. (2002). 'The recent performance of the UK labour market', Oxford Review of Economic Policy, 18, pp. 202-220

Nickell, S. and Van Ours, J. (2000),.'The Netherlands and the UK: A European unemployment miracle?', Economic Policy, 30, pp. 137-180.

Oaxaca, R. and Ransom, M. (1994). 'On discrimination and the decomposition of wage differentials', Journal of Econometrics, 61, pp. 5-21.

Schweitzer, M. (2003).'Ready, willing and able? Measuring labour availability in the 
UK, Working paper no. 186, Bank of England.

Turok, I and Edge, N. (1999). The jobs gap in Britain's cities: employment loss and labour market consequences, Policy Press, Bristol. 


\section{Data Appendix}

\section{Variables used in the Analysis}

$\begin{array}{ll}\text { Age } & \\ \text { ageband1 } & \text { aged } 16-20 \\ \text { ageband2 } & \text { aged } 21-25 \\ \text { ageband3 } & \text { aged } 26-30 \\ \text { ageband4 } & \text { aged } 31-35 \\ \text { ageband5 } & \text { aged } 36-40 \\ \text { ageband6 } & \text { aged } 41-45 \\ \text { ageband7 } & \text { aged } 46-50 \\ \text { ageband8 } & \text { aged } 51-55 \\ \text { ageband9 } & \text { aged } 56+ \\ & \\ \text { Marital Status } & \\ \text { marstat1 } & \text { married/cohabiting } \\ \text { marstat2 } & \text { single } \\ \text { marstat3 } & \text { widowed/divorced/separated }\end{array}$

Highest Educational Qualification

hquall Degree

hqual2 Higher education

hqual3 A-levels

hqual4 O-levels

hqual5 Other qualifications

hqual6 No qualifications

Housing Tenure

hsetype 1

Has mortgage

hsetype 2

Owned outright

hsetype 3

Subsidised housing (council housing)

hsetype 4

Other (private rented)

Children

kids0

kids 1

kids2

kids3

yngkids

No children in the family

1 child in the family

2 children in the family

$3+$ children in the family

Pre-school children in the family

Household Head

Hoh

Head of household

Ethnicity

Coloured

Non-white

Health

Ill

Long term illness 
Chart 1: UK Employment and ILO Unemployment Rates

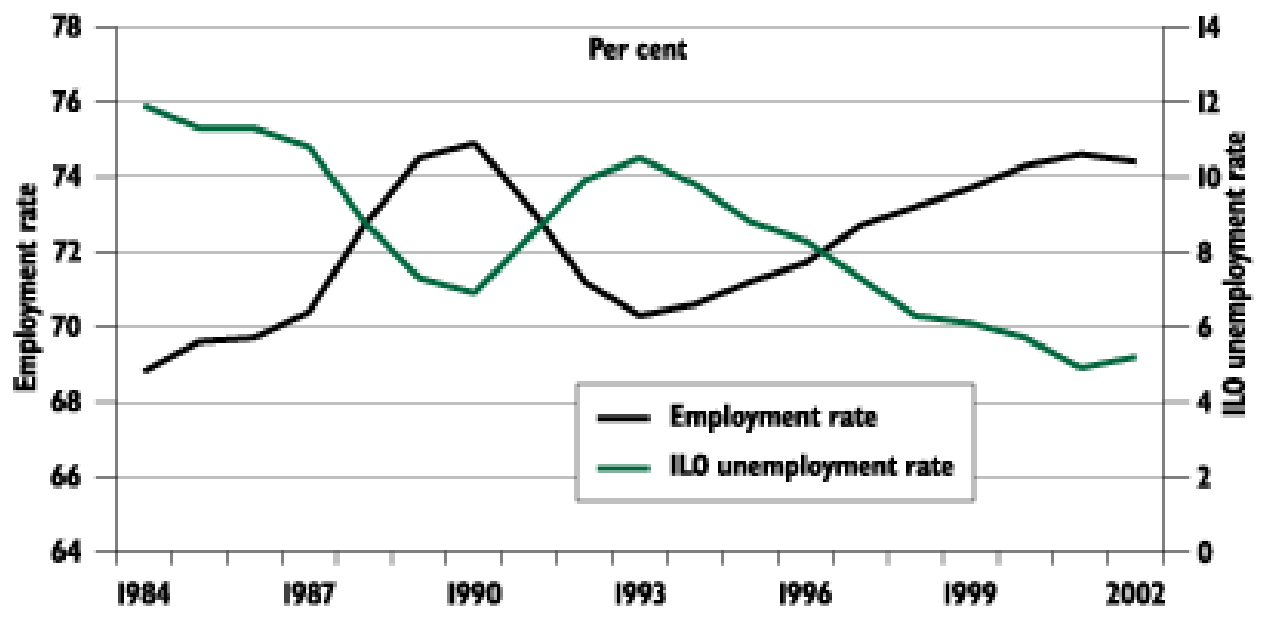

Source: HM Treasury Pre-Budget Report 2001 
Table 1: Labour Market Status in Great Britain Region: Males and Females

\begin{tabular}{|c|c|c|c|c|c|c|c|c|}
\hline & \multirow{2}{*}{\multicolumn{2}{|c|}{ Employment }} & \multirow{2}{*}{\multicolumn{2}{|c|}{ Unemployment }} & \multirow{2}{*}{\multicolumn{2}{|c|}{ Economic Inactivity }} & \multicolumn{2}{|c|}{ Per cent } \\
\hline & & & & & & & Sam & ize \\
\hline & Male & Female & Male & Female & Male & Female & Male & Female \\
\hline Great Britain & 81.10 & 70.36 & 5.40 & 3.69 & 13.50 & 25.95 & 152733 & 149437 \\
\hline Northern & 73.05 & 65.68 & 7.56 & 4.61 & 19.39 & 29.71 & 8597 & 8328 \\
\hline Yorkshire \& Humberside & 79.36 & 69.93 & 6.00 & 3.86 & 14.64 & 26.21 & 13884 & 13512 \\
\hline East Midlands & 82.69 & 71.85 & 4.73 & 3.35 & 12.58 & 24.80 & 11249 & 10852 \\
\hline East Anglia & 84.99 & 73.05 & 4.23 & 3.51 & 10.78 & 23.44 & 6190 & 5806 \\
\hline London & 80.12 & 66.77 & 6.92 & 4.91 & 12.96 & 28.32 & 16701 & 17280 \\
\hline South East & 87.05 & 74.00 & 3.56 & 2.91 & 9.40 & 23.09 & 29807 & 28959 \\
\hline South West & 84.85 & 75.01 & 3.97 & 3.35 & 11.19 & 21.64 & 12736 & 12320 \\
\hline West Midlands & 81.58 & 69.42 & 5.61 & 3.89 & 12.81 & 26.69 & 13999 & 13482 \\
\hline North West & 77.46 & 67.96 & 5.90 & 2.97 & 16.64 & 29.07 & 17083 & 16811 \\
\hline Wales & 74.52 & 65.87 & 6.26 & 3.75 & 19.22 & 30.38 & 7951 & 7759 \\
\hline Scotland & 77.70 & 70.41 & 6.63 & 4.31 & 15.67 & 25.29 & 14536 & 14328 \\
\hline
\end{tabular}


Table 2: Variable Means by Labour Market Status: Great Britain

\begin{tabular}{|c|c|c|c|c|c|c|c|c|}
\hline & \multicolumn{2}{|c|}{ Employed } & \multicolumn{2}{|c|}{ Unemployed } & \multicolumn{2}{|c|}{ Inactive } & \multicolumn{2}{|c|}{ Total Sample } \\
\hline & Male & Female & Male & Female & Male & Female & Male & Female \\
\hline ageband1 & 0.047 & 0.046 & 0.169 & 0.156 & 0.023 & 0.032 & 0.051 & 0.046 \\
\hline ageband 2 & 0.081 & 0.088 & 0.141 & 0.142 & 0.031 & 0.071 & 0.077 & 0.086 \\
\hline ageband3 & 0.116 & 0.126 & 0.122 & 0.147 & 0.042 & 0.119 & 0.106 & 0.125 \\
\hline ageband4 & 0.139 & 0.145 & 0.114 & 0.136 & 0.052 & 0.148 & 0.126 & 0.146 \\
\hline ageband5 & 0.139 & 0.149 & 0.102 & 0.129 & 0.065 & 0.128 & 0.127 & 0.143 \\
\hline ageband6 & 0.126 & 0.135 & 0.085 & 0.102 & 0.071 & 0.102 & 0.116 & 0.125 \\
\hline ageband 7 & 0.122 & 0.132 & 0.087 & 0.078 & 0.092 & 0.107 & 0.116 & 0.124 \\
\hline ageband8 & 0.095 & 0.100 & 0.066 & 0.060 & 0.107 & 0.115 & 0.093 & 0.102 \\
\hline ageband 9 & 0.135 & 0.080 & 0.113 & 0.050 & 0.518 & 0.179 & 0.186 & 0.104 \\
\hline marstat1 & 0.733 & 0.714 & 0.421 & 0.451 & 0.650 & 0.687 & 0.705 & 0.697 \\
\hline marstat2 & 0.212 & 0.182 & 0.478 & 0.373 & 0.208 & 0.149 & 0.226 & 0.180 \\
\hline marstat3 & 0.055 & 0.105 & 0.101 & 0.177 & 0.142 & 0.165 & 0.069 & 0.123 \\
\hline hqual1 & 0.154 & 0.140 & 0.081 & 0.092 & 0.057 & 0.049 & 0.137 & 0.115 \\
\hline hqual2 & 0.120 & 0.148 & 0.067 & 0.070 & 0.070 & 0.063 & 0.111 & 0.123 \\
\hline hqual3 & 0.317 & 0.176 & 0.239 & 0.167 & 0.254 & 0.122 & 0.304 & 0.162 \\
\hline hqual4 & 0.136 & 0.233 & 0.133 & 0.226 & 0.076 & 0.186 & 0.127 & 0.220 \\
\hline hqual5 & 0.143 & 0.147 & 0.193 & 0.197 & 0.146 & 0.170 & 0.146 & 0.155 \\
\hline hqual6 & 0.131 & 0.156 & 0.287 & 0.248 & 0.397 & 0.411 & 0.175 & 0.225 \\
\hline hoh & 0.847 & 0.179 & 0.647 & 0.343 & 0.880 & 0.268 & 0.841 & 0.208 \\
\hline hsetype1 & 0.651 & 0.660 & 0.294 & 0.347 & 0.235 & 0.357 & 0.576 & 0.570 \\
\hline hsetype2 & 0.163 & 0.148 & 0.142 & 0.099 & 0.336 & 0.192 & 0.185 & 0.158 \\
\hline hsetype 3 & 0.102 & 0.114 & 0.416 & 0.403 & 0.358 & 0.354 & 0.153 & 0.187 \\
\hline hsetype 4 & 0.084 & 0.079 & 0.148 & 0.150 & 0.072 & 0.097 & 0.086 & 0.086 \\
\hline kids1 & 0.168 & 0.197 & 0.156 & 0.237 & 0.089 & 0.204 & 0.157 & 0.200 \\
\hline kids2 & 0.179 & 0.189 & 0.111 & 0.203 & 0.063 & 0.217 & 0.160 & 0.197 \\
\hline kids3 & 0.071 & 0.062 & 0.084 & 0.105 & 0.050 & 0.152 & 0.068 & 0.087 \\
\hline yngkids & 0.159 & 0.142 & 0.130 & 0.210 & 0.057 & 0.315 & 0.144 & 0.189 \\
\hline coloured & 0.053 & 0.049 & 0.113 & 0.116 & 0.069 & 0.109 & 0.059 & 0.067 \\
\hline ill & 0.086 & 0.080 & 0.200 & 0.171 & 0.676 & 0.358 & 0.172 & 0.156 \\
\hline
\end{tabular}

Note: Variables defined in the data appendix. 
Table 3.1: Multinomial Logit Estimates of Labour Market Status for Males: Great Britain (excluding students), Specification 1

\begin{tabular}{|c|c|c|c|c|c|}
\hline & \multicolumn{2}{|c|}{ Employment } & \multicolumn{2}{|c|}{ Inactivity } & \multirow{2}{*}{$\frac{\text { Unemployment }}{\text { Marginal }}$} \\
\hline & Coefficient & Marginal & Coefficient & Marginal & \\
\hline ageband1 & $\begin{array}{c}-0.748 \\
{[0.000]}\end{array}$ & -0.022 & $\begin{array}{l}-1.147 \\
{[0.000]}\end{array}$ & -0.015 & 0.037 \\
\hline ageband2 & $\begin{array}{c}-0.334 \\
{[0.000]}\end{array}$ & -0.001 & $\begin{array}{c}-0.687 \\
{[0.000]}\end{array}$ & -0.013 & 0.014 \\
\hline ageband3 & $\begin{array}{c}-0.061 \\
{[0.214]}\end{array}$ & 0.005 & $\begin{array}{c}-0.252 \\
{[0.000]}\end{array}$ & -0.007 & 0.002 \\
\hline ageband5 & $\begin{array}{l}-0.002 \\
{[0.969]}\end{array}$ & -0.013 & $\begin{array}{c}0.278 \\
{[0.000]}\end{array}$ & 0.013 & -0.000 \\
\hline ageband6 & $\begin{array}{c}-0.006 \\
{[0.909]}\end{array}$ & -0.026 & $\begin{array}{c}0.512 \\
{[0.000]}\end{array}$ & 0.027 & -0.001 \\
\hline ageband7 & $\begin{array}{c}-0.127 \\
{[0.021]}\end{array}$ & -0.051 & $\begin{array}{c}0.687 \\
{[0.000]}\end{array}$ & 0.048 & 0.003 \\
\hline ageband 8 & $\begin{array}{c}-0.150 \\
{[0.012]}\end{array}$ & -0.085 & $\begin{array}{c}1.031 \\
{[0.000]}\end{array}$ & 0.083 & 0.002 \\
\hline ageband9 & $\begin{array}{c}-0.350 \\
{[0.000]}\end{array}$ & -0.265 & $\begin{array}{c}1.962 \\
{[0.000]}\end{array}$ & 0.264 & 0.001 \\
\hline martstat2 & $\begin{array}{l}-1.020 \\
{[0.000]}\end{array}$ & -0.089 & $\begin{array}{l}-0.289 \\
{[0.000]}\end{array}$ & 0.037 & 0.052 \\
\hline marstat3 & $\begin{array}{c}-0.914 \\
{[0.000]}\end{array}$ & -0.076 & $\begin{array}{l}-0.270 \\
{[0.000]}\end{array}$ & 0.032 & 0.044 \\
\hline hqual1 & $\begin{array}{c}0.842 \\
{[0.000]}\end{array}$ & 0.049 & $\begin{array}{c}-0.413 \\
{[0.000]}\end{array}$ & -0.030 & -0.019 \\
\hline hqual2 & $\begin{array}{c}0.772 \\
{[0.000]}\end{array}$ & 0.043 & $\begin{array}{c}-0.180 \\
{[0.002]}\end{array}$ & -0.025 & -0.018 \\
\hline hqual3 & $\begin{array}{c}0.588 \\
{[0.000]}\end{array}$ & 0.038 & $\begin{array}{l}-0.230 \\
{[0.000]}\end{array}$ & -0.023 & -0.015 \\
\hline hqual4 & $\begin{array}{c}0.586 \\
{[0.000]}\end{array}$ & 0.037 & $\begin{array}{c}-0.221 \\
{[0.000]}\end{array}$ & -0.022 & -0.015 \\
\hline hqual5 & $\begin{array}{c}0.371 \\
{[0.000]}\end{array}$ & 0.030 & $\begin{array}{l}-0.315 \\
{[0.000]}\end{array}$ & -0.020 & -0.010 \\
\hline hoh & $\begin{array}{c}-0.021 \\
{[0.611]}\end{array}$ & -0.002 & $\begin{array}{c}0.024 \\
{[0.627]}\end{array}$ & 0.001 & 0.001 \\
\hline hsetype2 & $\begin{array}{l}-0.464 \\
{[0.000]}\end{array}$ & -0.075 & $\begin{array}{c}0.494 \\
{[0.000]}\end{array}$ & 0.059 & 0.016 \\
\hline hsetype 3 & $\begin{array}{l}-1.762 \\
{[0.000]}\end{array}$ & -0.279 & $\begin{array}{c}0.225 \\
{[0.000]}\end{array}$ & 0.174 & 0.105 \\
\hline hsetype 4 & $\begin{array}{c}-1.115 \\
{[0.000]}\end{array}$ & -0.112 & $\begin{array}{l}-0.168 \\
{[0.001]}\end{array}$ & 0.054 & 0.058 \\
\hline kids1 & $\begin{array}{c}-0.044 \\
{[0.254]}\end{array}$ & 0.002 & $\begin{array}{l}-0.131 \\
{[0.005]}\end{array}$ & -0.004 & 0.002 \\
\hline kids2 & $\begin{array}{c}0.045 \\
{[0.327]}\end{array}$ & 0.009 & $\begin{array}{l}-0.154 \\
{[0.005]}\end{array}$ & -0.008 & -0.001 \\
\hline kids3 & $\begin{array}{l}-0.295 \\
{[0.000]}\end{array}$ & -0.020 & $\begin{array}{c}-0.083 \\
{[0.198]}\end{array}$ & 0.009 & 0.011 \\
\hline yngkids & $\begin{array}{c}-0.163 \\
{[0.000]}\end{array}$ & -0.007 & $\begin{array}{c}-0.135 \\
{[0.020]}\end{array}$ & 0.001 & 0.006 \\
\hline coloured & $\begin{array}{l}-0.672 \\
{[0.000]}\end{array}$ & -0.049 & $\begin{array}{c}-0.230 \\
{[0.000]}\end{array}$ & 0.020 & 0.029 \\
\hline constant & $\begin{array}{c}3.250 \\
{[0.000]}\end{array}$ & & $\begin{array}{c}0.161 \\
{[0.097]}\end{array}$ & & \\
\hline
\end{tabular}

Notes:

1. $\mathrm{p}$-values in square brackets.

2. Additional controls for year and month of interview were included in the model but not reported in the table.

3. Marginal probabilities measured relative to the baseline individual who is married, white, non-head of household, owner-occupier, with no children or qualifications, and aged between 31-35 years of age.

4. Variables defined in the data appendix. 
Table 3.2: Multinomial Logit Estimates of Labour Market Status for Females: Great Britain (excluding students), Specification1

\begin{tabular}{|c|c|c|c|c|c|}
\hline & \multicolumn{2}{|c|}{ Employment } & \multicolumn{2}{|c|}{ Inactivity } & \multirow{2}{*}{$\begin{array}{c}\text { Unemployment } \\
\text { Marginal } \\
\end{array}$} \\
\hline & Coefficient & Marginal & Coefficient & Marginal & \\
\hline ageband1 & $\begin{array}{c}-1.104 \\
{[0.000]}\end{array}$ & -0.033 & $\begin{array}{l}-1.171 \\
{[0.000]}\end{array}$ & -0.014 & 0.047 \\
\hline ageband2 & $\begin{array}{c}-0.506 \\
{[0.000]}\end{array}$ & -0.012 & $\begin{array}{c}-0.521 \\
{[0.000]}\end{array}$ & -0.004 & 0.016 \\
\hline ageband3 & $\begin{array}{c}-0.217 \\
{[0.000]}\end{array}$ & -0.001 & $\begin{array}{l}-0.255 \\
{[0.000]}\end{array}$ & -0.005 & 0.006 \\
\hline ageband5 & $\begin{array}{c}0.005 \\
{[0.923]}\end{array}$ & -0.010 & $\begin{array}{c}0.095 \\
{[0.097]}\end{array}$ & 0.011 & -0.001 \\
\hline ageband6 & $\begin{array}{r}-0.0127 \\
{[0.833]}\end{array}$ & -0.042 & $\begin{array}{c}0.314 \\
{[0.000]}\end{array}$ & 0.043 & -0.001 \\
\hline ageband7 & $\begin{array}{c}0.105 \\
{[0.115]}\end{array}$ & -0.089 & $\begin{array}{c}0.747 \\
{[0.000]}\end{array}$ & 0.094 & -0.005 \\
\hline ageband 8 & $\begin{array}{c}0.001 \\
{[0.988]}\end{array}$ & -0.167 & $\begin{array}{c}1.045 \\
{[0.000]}\end{array}$ & 0.172 & -0.005 \\
\hline ageband9 & $\begin{array}{l}-0.0201 \\
{[0.801]}\end{array}$ & -0.302 & $\begin{array}{c}1.620 \\
{[0.000]}\end{array}$ & 0.311 & -0.009 \\
\hline martstat2 & $\begin{array}{c}-0.513 \\
{[0.000]}\end{array}$ & -0.001 & $\begin{array}{c}-0.640 \\
{[0.000]}\end{array}$ & -0.016 & 0.017 \\
\hline marstat3 & $\begin{array}{c}-0.519 \\
{[0.000]}\end{array}$ & 0.009 & $\begin{array}{c}-0.747 \\
{[0.000]}\end{array}$ & -0.026 & 0.017 \\
\hline hquall & $\begin{array}{c}0.528 \\
{[0.000]}\end{array}$ & 0.110 & $\begin{array}{l}-1.003 \\
{[0.000]}\end{array}$ & -0.102 & -0.008 \\
\hline hqual2 & $\begin{array}{c}0.905 \\
{[0.000]}\end{array}$ & 0.113 & $\begin{array}{l}-0.563 \\
{[0.000]}\end{array}$ & -0.100 & -0.013 \\
\hline hqual3 & $\begin{array}{c}0.443 \\
{[0.000]}\end{array}$ & 0.087 & $\begin{array}{c}-0.547 \\
{[0.000]}\end{array}$ & -0.080 & -0.007 \\
\hline hqual4 & $\begin{array}{c}0.407 \\
{[0.000]}\end{array}$ & 0.082 & $\begin{array}{c}-0.500 \\
{[0.000]}\end{array}$ & -0.075 & -0.007 \\
\hline hqual5 & $\begin{array}{r}0.159 \\
{[0.000]}\end{array}$ & 0.066 & $\begin{array}{c}-0.566 \\
{[0.000]}\end{array}$ & -0.064 & -0.002 \\
\hline hoh & $\begin{array}{c}-0.136 \\
{[0.012]}\end{array}$ & -0.048 & $\begin{array}{c}0.215 \\
{[0.000]}\end{array}$ & 0.046 & 0.002 \\
\hline hsetype2 & $\begin{array}{c}-0.269 \\
{[0.000]}\end{array}$ & -0.107 & $\begin{array}{c}0.439 \\
{[0.000]}\end{array}$ & 0.103 & 0.004 \\
\hline hsetype3 & $\begin{array}{c}-1.402 \\
{[0.000]}\end{array}$ & -0.272 & $\begin{array}{c}-0.017 \\
{[0.654]}\end{array}$ & 0.229 & 0.043 \\
\hline hsetype4 & $\begin{array}{c}-1.019 \\
{[0.000]}\end{array}$ & -0.171 & $\begin{array}{c}-0.076 \\
{[0.122]}\end{array}$ & 0.141 & 0.030 \\
\hline kids 1 & $\begin{array}{c}-0.153 \\
{[0.000]}\end{array}$ & -0.051 & $\begin{array}{c}0.220 \\
{[0.000]}\end{array}$ & 0.049 & 0.002 \\
\hline kids2 & $\begin{array}{c}-0.367 \\
{[0.000]}\end{array}$ & -0.101 & $\begin{array}{c}0.291 \\
{[0.000]}\end{array}$ & 0.094 & 0.007 \\
\hline kids3 & $\begin{array}{c}-0.628 \\
{[0.000]}\end{array}$ & -0.188 & $\begin{array}{c}0.462 \\
{[0.000]}\end{array}$ & 0.177 & 0.011 \\
\hline yngkids & $\begin{array}{c}-0.272 \\
{[0.000]}\end{array}$ & -0.235 & $\begin{array}{r}1.068 \\
{[0.000]}\end{array}$ & 0.236 & -0.001 \\
\hline coloured & $\begin{array}{c}-0.723 \\
{[0.000]}\end{array}$ & -0.115 & $\begin{array}{c}-0.040 \\
{[0.398]}\end{array}$ & 0.096 & 0.019 \\
\hline constant & $\begin{array}{c}3.460 \\
{[0.000]}\end{array}$ & & $\begin{array}{c}1.696 \\
{[0.000]}\end{array}$ & & \\
\hline
\end{tabular}

Notes:

1. p-values in square brackets.

2. Additional controls for year and month of interview were included in the model but not reported in the table.

3. Marginal probabilities measured relative to the baseline individual who is married, white, non-head of household, owner-occupier, with no children or qualifications, and aged between 31-35 years of age.

4. Variables defined in the data appendix. 
Table 4.1 Decomposition of Employment, Unemployment and Inactivity Rate Differences: Males Excluding Students, Specification 1, LFS 1997(1)-2001(4) $)^{1,2}$

\begin{tabular}{|c|c|c|c|c|c|c|c|c|c|}
\hline & \multicolumn{3}{|c|}{ Employment } & \multicolumn{3}{|c|}{ Unemployment } & \multicolumn{3}{|c|}{ Inactivity } \\
\hline & Differential & Composition & Structure & Differential & Composition & Structure & Differential & Composition & Structure \\
\hline Northern & -0.085 & $\begin{array}{l}-0.017 \\
(20.28)\end{array}$ & $\begin{array}{c}-0.068 \\
(79.72)\end{array}$ & 0.023 & $\begin{array}{c}0.003 \\
(13.38)\end{array}$ & $\begin{array}{c}0.020 \\
(86.62)\end{array}$ & 0.062 & $\begin{array}{c}0.014 \\
(22.81)\end{array}$ & $\begin{array}{c}0.048 \\
(77.19)\end{array}$ \\
\hline $\begin{array}{c}\text { Yorkshire } \\
\text { Humberside }\end{array}$ & -0.019 & $\begin{array}{l}-0.003 \\
(14.15)\end{array}$ & $\begin{array}{l}-0.016 \\
(85.85)\end{array}$ & 0.007 & $\begin{array}{l}0.000 \\
(3.17)\end{array}$ & $\begin{array}{c}0.007 \\
(96.83)\end{array}$ & 0.013 & $\begin{array}{c}0.003 \\
(19.86)\end{array}$ & $\begin{array}{c}0.010 \\
(80.14)\end{array}$ \\
\hline $\begin{array}{c}\text { East } \\
\text { Midlands }\end{array}$ & 0.017 & $\begin{array}{c}0.006 \\
(32.24)\end{array}$ & $\begin{array}{c}0.011 \\
(67.76)\end{array}$ & -0.007 & $\begin{array}{c}-0.004 \\
(55.92)\end{array}$ & $\begin{array}{l}-0.003 \\
(44.08)\end{array}$ & -0.010 & $\begin{array}{c}-0.002 \\
(14.85)\end{array}$ & $\begin{array}{c}-0.008 \\
(85.15)\end{array}$ \\
\hline East Anglia & 0.041 & $\begin{array}{c}0.009 \\
(21.79)\end{array}$ & $\begin{array}{c}0.032 \\
(78.21)\end{array}$ & -0.012 & $\begin{array}{c}-0.004 \\
(33.38)\end{array}$ & $\begin{array}{l}-0.008 \\
(66.62)\end{array}$ & -0.028 & $\begin{array}{l}-0.005 \\
(16.81)\end{array}$ & $\begin{array}{l}-0.023 \\
(83.19)\end{array}$ \\
\hline London & -0.011 & $\begin{array}{c}-0.026 \\
(233.98)\end{array}$ & $\begin{array}{c}0.015 \\
(-133.98)\end{array}$ & 0.017 & $\begin{array}{c}0.019 \\
(114.41)\end{array}$ & $\begin{array}{c}-0.002 \\
(-14.41)\end{array}$ & -0.006 & $\begin{array}{c}0.006 \\
(-104.95)\end{array}$ & $\begin{array}{c}-0.012 \\
(204.95)\end{array}$ \\
\hline South East & 0.074 & $\begin{array}{c}0.031 \\
(41.35)\end{array}$ & $\begin{array}{c}0.043 \\
(58.65)\end{array}$ & -0.023 & $\begin{array}{l}-0.010 \\
(42.49)\end{array}$ & $\begin{array}{l}-0.013 \\
(57.51)\end{array}$ & -0.051 & $\begin{array}{l}-0.021 \\
(40.84)\end{array}$ & $\begin{array}{l}-0.030 \\
(59.16)\end{array}$ \\
\hline South West & 0.041 & $\begin{array}{c}0.022 \\
(52.61)\end{array}$ & $\begin{array}{c}0.019 \\
(47.39)\end{array}$ & -0.016 & $\begin{array}{c}-0.009 \\
(57.59) \\
\end{array}$ & $\begin{array}{l}-0.007 \\
(42.41)\end{array}$ & -0.025 & $\begin{array}{l}-0.013 \\
(49.51) \\
\end{array}$ & $\begin{array}{c}-0.012 \\
(50.49) \\
\end{array}$ \\
\hline $\begin{array}{c}\text { West } \\
\text { Midlands }\end{array}$ & 0.005 & $\begin{array}{c}-0.011 \\
(-213.87)\end{array}$ & $\begin{array}{c}0.016 \\
(313.87)\end{array}$ & 0.002 & $\begin{array}{c}0.003 \\
(116.88)\end{array}$ & $\begin{array}{c}-0.001 \\
(-16.88)\end{array}$ & -0.008 & $\begin{array}{c}0.009 \\
(-112.47)\end{array}$ & $\begin{array}{c}-0.017 \\
(212.47)\end{array}$ \\
\hline North West & -0.041 & $\begin{array}{l}-0.005 \\
(11.53) \\
\end{array}$ & $\begin{array}{c}-0.036 \\
(88.47)\end{array}$ & 0.006 & $\begin{array}{l}0.000 \\
(3.57)\end{array}$ & $\begin{array}{c}0.006 \\
(96.43) \\
\end{array}$ & 0.035 & $\begin{array}{c}0.005 \\
(12.79) \\
\end{array}$ & $\begin{array}{c}0.030 \\
(87.21)\end{array}$ \\
\hline Wales & -0.069 & $\begin{array}{c}-0.013 \\
(18.15)\end{array}$ & $\begin{array}{l}-0.056 \\
(81.85)\end{array}$ & 0.009 & $\begin{array}{c}-0.001 \\
(-14.24)\end{array}$ & $\begin{array}{c}0.010 \\
(114.24)\end{array}$ & 0.060 & $\begin{array}{c}0.014 \\
(23.02)\end{array}$ & $\begin{array}{c}0.046 \\
(76.98)\end{array}$ \\
\hline Scotland & -0.038 & $\begin{array}{c}-0.017 \\
(45.99)\end{array}$ & $\begin{array}{c}-0.021 \\
(54.11)\end{array}$ & 0.014 & $\begin{array}{c}0.005 \\
(34.62)\end{array}$ & $\begin{array}{c}0.009 \\
(65.38)\end{array}$ & 0.024 & $\begin{array}{c}0.013 \\
(52.42)\end{array}$ & $\begin{array}{c}0.011 \\
(47.58)\end{array}$ \\
\hline
\end{tabular}

1. $\quad$ All entries outside parentheses rounded to three decimal places.

2. Figures in parentheses indicate the percentage of the raw differential attributed to each component. 
Table 4.2 Breakdown of Composition Effect: Specification 1, Males

\begin{tabular}{|c|c|c|c|c|c|c|c|c|c|}
\hline & \multicolumn{3}{|c|}{ Northern } & \multicolumn{3}{|c|}{ Yorkshire and Humberside } & \multicolumn{3}{|c|}{ East Midlands } \\
\hline & Employment & Inactivity & Unemployment & Employment & Inactivity & Unemployment & Employment & Inactivity & Unemployment \\
\hline Age & 4.06 & 4.57 & 1.61 & -7.92 & -11.11 & 1.77 & -14.81 & -6.82 & -1.12 \\
\hline Marital Status & 0.31 & 0.35 & 0.52 & -3.31 & -4.64 & -1.95 & 22.56 & 10.39 & 24.04 \\
\hline Qualifications & 7.04 & 7.92 & 5.20 & 23.85 & 33.49 & 7.18 & -26.54 & -12.22 & -14.83 \\
\hline Head/Household & -0.03 & -0.03 & -0.02 & 0.12 & 0.17 & 0.02 & -0.67 & -0.31 & -0.24 \\
\hline Housing Tenure & 12.56 & 14.13 & 11.97 & 7.34 & 10.30 & 0.65 & 45.14 & 20.79 & 41.70 \\
\hline Children & -0.15 & -0.16 & -0.34 & -0.75 & -1.05 & -0.58 & 2.55 & 1.18 & 1.50 \\
\hline Ethnicity & -3.76 & -4.22 & -6.42 & -4.86 & -6.82 & -3.18 & 4.99 & 2.30 & 5.79 \\
\hline \multirow[t]{3}{*}{ Month and Year } & 0.23 & 0.26 & 0.85 & $\begin{array}{ll}-0.33 \\
\end{array}$ & $\begin{array}{l}-0.47 \\
\end{array}$ & $\begin{array}{ll}-0.73 \\
\end{array}$ & -0.98 & $\begin{array}{l}-0.45 \\
\end{array}$ & -0.92 \\
\hline & \multicolumn{3}{|c|}{ East Anglia } & \multicolumn{3}{|c|}{ London } & \multicolumn{3}{|c|}{ South East } \\
\hline & Employment & Inactivity & Unemployment & Employment & Inactivity & Unemployment & Employment & Inactivity & Unemployment \\
\hline Age & -9.80 & -7.56 & -1.94 & -230.35 & 103.32 & -6.59 & -4.09 & -4.04 & 1.21 \\
\hline Marital Status & 8.80 & 6.78 & 10.90 & 107.78 & $\begin{array}{l}-498.34 \\
\end{array}$ & 26.29 & 5.44 & 5.38 & 7.77 \\
\hline Qualifications & -2.56 & -1.97 & -3.32 & -72.63 & 32.58 & -4.62 & 10.91 & 10.78 & 8.25 \\
\hline Head/Household & -0.36 & $\begin{array}{ll}-0.28 \\
\end{array}$ & -0.15 & -1.95 & 0.88 & -0.16 & -0.18 & $\begin{array}{ll}-0.18 \\
\end{array}$ & $\begin{array}{ll}-0.09 \\
\end{array}$ \\
\hline Housing Tenure & 13.52 & 10.43 & 10.10 & 237.52 & -106.54 & 50.00 & 26.35 & 26.02 & 21.85 \\
\hline Children & 0.84 & -0.65 & 1.09 & 11.49 & -5.16 & 1.86 & 0.14 & 0.14 & -0.60 \\
\hline Ethnicity & 12.17 & 9.39 & 16.43 & 182.66 & -81.93 & 48.57 & 2.62 & 2.59 & 4.06 \\
\hline \multirow[t]{3}{*}{ Month and Year } & 0.87 & 0.67 & 0.27 & -0.55 & 0.25 & $\begin{array}{c}-0.58 \\
\end{array}$ & 0.16 & 0.16 & 0.04 \\
\hline & \multicolumn{3}{|c|}{ South West } & \multicolumn{3}{|c|}{ West Midlands } & \multicolumn{3}{|c|}{ North West } \\
\hline & Employment & Inactivity & Unemployment & Employment & Inactivity & Unemployment & Employment & Inactivity & Unemployment \\
\hline Age & -16.94 & $\begin{array}{l}-15.94 \\
\end{array}$ & 0.02 & -30.91 & $\begin{array}{l}-16.26 \\
\end{array}$ & 9.82 & -0.26 & $\begin{array}{l}-0.29 \\
\end{array}$ & 2.57 \\
\hline Marital Status & 8.87 & 8.35 & 10.21 & 11.81 & 6.21 & -13.20 & 5.90 & 6.55 & 10.69 \\
\hline Qualifications & 18.40 & 17.32 & 11.65 & -114.65 & -60.29 & 70.24 & 9.58 & 10.63 & 6.80 \\
\hline Head/Household & -0.36 & $\begin{array}{l}-0.34 \\
\end{array}$ & $\begin{array}{l}-0.14 \\
\end{array}$ & 1.75 & 0.92 & -0.65 & -0.23 & -0.25 & -0.14 \\
\hline Housing Tenure & 33.31 & 31.35 & 23.52 & -48.03 & -25.26 & -2.01 & $\begin{array}{ll}-0.69 \\
\end{array}$ & -0.76 & -8.50 \\
\hline Children & -0.16 & -0.15 & $\begin{array}{l}-0.41 \\
\end{array}$ & -0.43 & -0.23 & 2.96 & 0.26 & 0.29 & $\begin{array}{ll}-0.31 \\
\end{array}$ \\
\hline Ethnicity & 9.46 & 8.90 & 11.85 & -32.27 & -16.97 & 39.24 & -3.08 & -3.42 & -6.06 \\
\hline \multirow[t]{3}{*}{ Month and Year } & 0.02 & 0.02 & 0.88 & -1.13 & $\begin{array}{l}-0.59 \\
\end{array}$ & 10.48 & 0.04 & 0.05 & $\begin{array}{l}-1.49 \\
\end{array}$ \\
\hline & \multicolumn{3}{|c|}{ Wales } & \multicolumn{3}{|c|}{ Scotland } & & & \\
\hline & Employment & Inactivity & Unemployment & Employment & Inactivity & Unemployment & & & \\
\hline Age & 7.14 & 9.06 & -6.59 & 0.59 & 0.67 & 1.68 & & & \\
\hline Marital Status & 0.27 & 0.34 & -1.65 & 6.21 & 7.07 & 7.48 & & & \\
\hline Qualifications & 9.06 & 11.48 & -27.48 & -5.01 & -5.70 & -5.32 & & & \\
\hline Head/Household & -0.10 & -0.12 & 0.21 & $\begin{array}{ll}-0.09 \\
\end{array}$ & -0.10 & $\begin{array}{ll}-0.03 \\
\end{array}$ & & & \\
\hline Housing Tenure & 5.10 & 6.46 & -2.39 & 56.44 & 64.33 & 46.62 & & & \\
\hline Children & $\begin{array}{l}-0.14 \\
\end{array}$ & -0.17 & 1.44 & -1.70 & -1.94 & -2.79 & & & \\
\hline Ethnicity & -3.13 & -3.97 & 21.43 & -10.80 & -12.31 & -14.12 & & & \\
\hline Month and Year & -0.04 & -0.05 & 0.81 & 0.35 & 0.40 & 1.10 & & & \\
\hline
\end{tabular}

Note: Entry in the table is the percentage of the raw difference attributable to each characteristic. 
Table 5.1 Decomposition of Employment, Unemployment and Inactivity Rate Differences: Females Excluding Students, Specification1, LFS 1997(1)-2001(4) ${ }^{1,2}$

\begin{tabular}{|c|c|c|c|c|c|c|c|c|c|}
\hline & \multicolumn{3}{|c|}{ Employment } & \multicolumn{3}{|c|}{ Unemployment } & \multicolumn{3}{|c|}{ Inactivity } \\
\hline & Differential & Composition & Structure & Differential & Composition & Structure & Differential & Composition & Structure \\
\hline Northern & -0.050 & $\begin{array}{c}-0.014 \\
(29.02)\end{array}$ & $\begin{array}{c}-0.036 \\
(70.92)\end{array}$ & 0.010 & $\begin{array}{c}0.002 \\
(24.74)\end{array}$ & $\begin{array}{c}0.008 \\
(75.26)\end{array}$ & 0.040 & $\begin{array}{c}0.012 \\
(30.08)\end{array}$ & $\begin{array}{c}0.028 \\
(69.92)\end{array}$ \\
\hline $\begin{array}{c}\text { Yorkshire } \\
\text { Humberside }\end{array}$ & -0.005 & $\begin{array}{c}-0.001 \\
(10.28)\end{array}$ & $\begin{array}{l}-0.004 \\
(89.78) \\
\end{array}$ & 0.002 & $\begin{array}{c}0.000 \\
(20.27)\end{array}$ & $\begin{array}{c}0.002 \\
(79.73) \\
\end{array}$ & 0.003 & $\begin{array}{l}0.000 \\
(3.47) \\
\end{array}$ & $\begin{array}{c}0.003 \\
(96.53) \\
\end{array}$ \\
\hline $\begin{array}{c}\text { East } \\
\text { Midlands }\end{array}$ & 0.016 & $\begin{array}{c}0.004 \\
(26.68)\end{array}$ & $\begin{array}{c}0.012 \\
(73.32)\end{array}$ & -0.004 & $\begin{array}{l}-0.003 \\
(89.77)\end{array}$ & $\begin{array}{c}-0.001 \\
(10.23)\end{array}$ & -0.012 & $\begin{array}{l}-0.001 \\
(8.38)\end{array}$ & $\begin{array}{l}-0.011 \\
(91.62)\end{array}$ \\
\hline East Anglia & 0.028 & $\begin{array}{c}0.017 \\
(59.14)\end{array}$ & $\begin{array}{c}0.011 \\
(40.86)\end{array}$ & -0.002 & $\begin{array}{c}-0.003 \\
(180.82)\end{array}$ & $\begin{array}{c}0.001 \\
(-80.82)\end{array}$ & -0.026 & $\begin{array}{l}-0.013 \\
(50.66)\end{array}$ & $\begin{array}{l}-0.013 \\
(49.34)\end{array}$ \\
\hline London & -0.041 & $\begin{array}{c}-0.045 \\
(110.83)\end{array}$ & $\begin{array}{c}0.004 \\
(-10.83)\end{array}$ & 0.014 & $\begin{array}{c}0.012 \\
(87.03)\end{array}$ & $\begin{array}{c}0.002 \\
(12.97)\end{array}$ & 0.027 & $\begin{array}{c}0.033 \\
(123.12)\end{array}$ & $\begin{array}{c}-0.006 \\
(-23.12)\end{array}$ \\
\hline South East & 0.045 & $\begin{array}{c}0.036 \\
(78.80) \\
\end{array}$ & $\begin{array}{c}0.009 \\
(21.20)\end{array}$ & -0.010 & $\begin{array}{c}-0.005 \\
(55.86)\end{array}$ & $\begin{array}{c}-0.005 \\
(44.14) \\
\end{array}$ & -0.036 & $\begin{array}{l}-0.030 \\
(85.01) \\
\end{array}$ & $\begin{array}{l}-0.006 \\
(14.91)\end{array}$ \\
\hline South West & 0.051 & $\begin{array}{c}0.032 \\
(62.93) \\
\end{array}$ & $\begin{array}{c}0.019 \\
(37.07) \\
\end{array}$ & -0.004 & $\begin{array}{c}-0.005 \\
(134.82) \\
\end{array}$ & $\begin{array}{c}0.001 \\
(-34.82) \\
\end{array}$ & -0.047 & $\begin{array}{l}-0.027 \\
(57.32)\end{array}$ & $\begin{array}{l}-0.020 \\
(42.68) \\
\end{array}$ \\
\hline $\begin{array}{c}\text { West } \\
\text { Midlands }\end{array}$ & -0.010 & $\begin{array}{c}-0.019 \\
(183.09) \\
\end{array}$ & $\begin{array}{c}0.009 \\
(-83.09) \\
\end{array}$ & 0.002 & $\begin{array}{l}0.000 \\
(5.68) \\
\end{array}$ & $\begin{array}{c}0.002 \\
(94.32) \\
\end{array}$ & 0.008 & $\begin{array}{c}0.019 \\
(230.29) \\
\end{array}$ & $\begin{array}{c}-0.011 \\
(-130.29) \\
\end{array}$ \\
\hline North West & -0.027 & $\begin{array}{l}-0.012 \\
(43.95) \\
\end{array}$ & $\begin{array}{l}-0.015 \\
(56.05) \\
\end{array}$ & -0.008 & $\begin{array}{l}0.000 \\
(-4.05) \\
\end{array}$ & $\begin{array}{c}-0.008 \\
(95.95) \\
\end{array}$ & 0.035 & $\begin{array}{c}0.012 \\
(32.96) \\
\end{array}$ & $\begin{array}{c}0.023 \\
(67.04) \\
\end{array}$ \\
\hline Wales & -0.047 & $\begin{array}{c}-0.014 \\
(29.13)\end{array}$ & $\begin{array}{c}-0.033 \\
(70.87)\end{array}$ & 0.001 & $\begin{array}{c}-0.001 \\
(-162.35)\end{array}$ & $\begin{array}{c}0.002 \\
(262.35)\end{array}$ & 0.047 & $\begin{array}{c}0.015 \\
(31.82)\end{array}$ & $\begin{array}{c}0.032 \\
(68.18)\end{array}$ \\
\hline Scotland & 0.000 & $\begin{array}{l}-0.000 \\
(-81.99)\end{array}$ & $\begin{array}{c}0.000 \\
(181.99)\end{array}$ & 0.007 & $\begin{array}{c}0.002 \\
(28.74)\end{array}$ & $\begin{array}{c}0.005 \\
(71.26)\end{array}$ & -0.007 & $\begin{array}{c}-0.002 \\
(21.04)\end{array}$ & $\begin{array}{c}-0.005 \\
(78.96)\end{array}$ \\
\hline
\end{tabular}

1. All entries outside parentheses rounded to three decimal places.

2. Figures in parentheses indicate the percentage of the raw differential attributed to each component. 
Table 5.2 Breakdown of Composition Effect: Specification 1, Females

\begin{tabular}{|c|c|c|c|c|c|c|c|c|c|}
\hline & \multicolumn{3}{|c|}{ Northern } & \multicolumn{3}{|c|}{ Yorkshire and Humberside } & \multicolumn{3}{|c|}{ East Midlands } \\
\hline & Employment & Inactivity & Unemployment & Employment & Inactivity & Unemployment & Employment & Inactivity & Unemployment \\
\hline Age & -0.22 & -0.22 & 4.48 & -50.45 & -17.02 & 104.80 & -15.83 & -4.97 & 2.14 \\
\hline Marital Status & -1.11 & -1.15 & 3.00 & 4.56 & 1.54 & -25.21 & -13.34 & -4.19 & 26.22 \\
\hline Qualifications & 29.79 & 30.87 & 11.66 & 184.82 & 62.36 & 118.41 & -117.45 & -36.90 & -31.50 \\
\hline Head/Household & 1.47 & 1.52 & 0.59 & -11.33 & -3.82 & -6.67 & 22.40 & 7.04 & 4.90 \\
\hline Housing Tenure & 15.43 & 15.99 & 18.75 & -0.11 & -0.04 & -19.34 & 99.38 & 31.22 & 69.17 \\
\hline Children & -3.04 & -3.15 & -0.92 & -48.95 & -16.51 & -30.51 & 24.26 & 7.62 & 5.31 \\
\hline Ethnicity & -13.58 & -14.07 & -14.93 & -66.67 & -22.49 & -107.25 & 26.16 & 8.22 & 15.65 \\
\hline \multirow[t]{3}{*}{ Month and Year } & 0.27 & 0.28 & 2.12 & -1.59 & $\begin{array}{l}-0.54 \\
\end{array}$ & -13.96 & 1.09 & $\begin{array}{l}0.34 \\
\end{array}$ & -2.12 \\
\hline & \multicolumn{3}{|c|}{ East Anglia } & \multicolumn{3}{|c|}{ London } & \multicolumn{3}{|c|}{ South East } \\
\hline & Employment & Inactivity & Unemployment & Employment & Inactivity & Unemployment & Employment & Inactivity & Unemployment \\
\hline Age & -29.73 & -25.46 & 0.88 & -42.73 & -47.50 & 0.91 & -7.79 & -8.40 & 3.58 \\
\hline Marital Status & -7.97 & -6.83 & 46.02 & -8.08 & -8.97 & 11.71 & -3.55 & -3.83 & 7.64 \\
\hline Qualifications & -9.87 & -8.46 & -16.00 & -34.13 & -37.92 & 0.04 & 35.24 & 38.01 & 10.05 \\
\hline Head/Household & 14.79 & 12.67 & 10.77 & 15.66 & 17.39 & 2.41 & 5.94 & 6.41 & 1.55 \\
\hline Housing Tenure & 24.01 & 20.57 & 57.28 & 67.76 & 75.28 & 32.10 & 41.32 & 44.57 & 26.56 \\
\hline Children & 39.79 & 34.08 & 28.53 & 22.97 & 25.52 & 2.39 & -1.94 & -2.09 & -0.76 \\
\hline Ethnicity & 28.50 & 24.41 & 56.73 & 89.58 & 99.51 & 37.70 & 9.53 & 10.28 & 6.81 \\
\hline \multirow[t]{3}{*}{ Month and Year } & -0.38 & -0.33 & -3.40 & -0.20 & -0.22 & -0.23 & 0.06 & 0.06 & 0.43 \\
\hline & \multicolumn{3}{|c|}{ South West } & \multicolumn{3}{|c|}{ West Midlands } & \multicolumn{3}{|c|}{ North West } \\
\hline & Employment & Inactivity & Unemployment & Employment & Inactivity & Unemployment & Employment & Inactivity & Unemployment \\
\hline Age & -10.67 & -9.72 & 4.83 & 15.73 & 19.79 & 0.40 & 1.49 & 1.12 & -0.61 \\
\hline Marital Status & -2.76 & -2.52 & 17.69 & 4.91 & 6.17 & -1.26 & -4.58 & -3.43 & -3.51 \\
\hline Qualifications & 29.23 & 26.63 & 30.44 & 104.26 & 131.14 & 3.76 & 36.86 & 27.65 & -3.12 \\
\hline Head/Household & 4.61 & 4.20 & 3.36 & -13.49 & -16.97 & $\begin{array}{l}-0.44 \\
\end{array}$ & 7.51 & 5.63 & -0.78 \\
\hline Housing Tenure & 22.67 & 20.65 & 46.49 & 1.62 & 2.04 & \begin{tabular}{ll|}
-1.71 \\
\end{tabular} & 3.44 & 2.58 & 1.20 \\
\hline Children & 4.85 & 4.42 & 1.74 & 33.04 & 41.56 & 1.14 & 10.40 & 7.80 & -1.24 \\
\hline Ethnicity & 15.03 & 13.69 & 29.92 & 34.69 & 43.63 & 3.07 & -10.47 & -7.85 & 2.98 \\
\hline \multirow[t]{3}{*}{ Month and Year } & $\begin{array}{l}-0.03 \\
\end{array}$ & -0.03 & 0.37 & 2.34 & 2.94 & 0.73 & -0.70 & -0.53 & 1.03 \\
\hline & \multicolumn{3}{|c|}{ Wales } & \multicolumn{3}{|c|}{ Scotland } & & & \\
\hline & Employment & Inactivity & Unemployment & Employment & Inactivity & Unemployment & & & \\
\hline Age & 8.99 & 9.82 & -150.11 & -11.73 & 3.01 & 1.31 & & & \\
\hline Marital Status & -0.46 & -0.50 & 32.04 & -21.34 & 5.48 & 15.00 & & & \\
\hline Qualifications & 18.87 & 20.61 & 412.46 & -31.06 & 7.97 & -16.02 & & & \\
\hline Head/Household & 1.23 & 1.35 & 34.37 & 34.93 & -8.97 & 2.98 & & & \\
\hline Housing Tenure & 8.90 & 9.72 & 273.15 & 302.22 & -77.57 & 79.00 & & & \\
\hline Children & 2.75 & 3.00 & 111.48 & -186.37 & 47.84 & -16.09 & & & \\
\hline Ethnicity & -11.29 & -12.33 & -859.45 & -169.86 & 43.60 & -39.67 & & & \\
\hline Month and Year & 0.13 & 0.15 & -16.28 & 1.22 & -0.31 & 2.24 & & & \\
\hline
\end{tabular}

Note: Entry in the table is the percentage of the raw difference attributable to each characteristic. 
Table 6 Marginal Effect of Reported Long-Term Illness on Labour Market Status by Region: Males and Females, Specification 2

\begin{tabular}{|c|c|c|c|c|c|c|}
\hline & \multicolumn{2}{|c|}{ Employment } & \multicolumn{2}{|c|}{ Inactivity } & \multicolumn{2}{|c|}{ Unemployment } \\
\hline & Male & Female & Male & Female & Male & Female \\
\hline Northern & -0.305 & 0.369 & 0.291 & 0.357 & 0.014 & 0.012 \\
\hline Yorkshire \& Humberside & -0.211 & -0.302 & 0.186 & 0.288 & 0.025 & 0.014 \\
\hline East Midlands & -0.199 & -0.255 & 0.183 & 0.243 & 0.016 & 0.012 \\
\hline East Anglia & -0.145 & -0.246 & 0.094 & 0.204 & 0.051 & 0.042 \\
\hline London & -0.178 & -0.303 & 0.155 & 0.300 & 0.023 & 0.003 \\
\hline South East & -0.133 & -0.231 & 0.114 & 0.217 & 0.019 & 0.014 \\
\hline South West & -0.151 & -0.220 & 0.126 & 0.200 & 0.025 & 0.020 \\
\hline West Midlands & -0.207 & -0.293 & 0.192 & 0.277 & 0.015 & 0.016 \\
\hline North West & -0.247 & -0.389 & 0.213 & 0.386 & 0.034 & 0.003 \\
\hline Wales & -0.403 & -0.475 & 0.367 & 0.467 & 0.036 & 0.008 \\
\hline Scotland & -0.261 & -0.343 & 0.247 & 0.328 & 0.014 & 0.015 \\
\hline Great Britain & -0.212 & -0.308 & 0.190 & 0.296 & 0.022 & 0.012 \\
\hline
\end{tabular}


Table 7 Incidence of Self-Reported Ill Health Across Regions

Percent

\begin{tabular}{|c|c|c|}
\hline & Male & Female \\
\hline Northern & 23.4 & 20.0 \\
\hline Yorkshire \& Humberside & 19.4 & 16.7 \\
\hline East Midlands & 16.2 & 14.6 \\
\hline East Anglia & 15.7 & 14.3 \\
\hline London & 15.2 & 14.6 \\
\hline South East & 13.0 & 12.2 \\
\hline South West & 16.3 & 13.8 \\
\hline West Midlands & 17.7 & 16.6 \\
\hline North West & 19.5 & 17.7 \\
\hline Wales & 22.6 & 20.0 \\
\hline Scotland & 18.6 & 16.7 \\
\hline Great Britain & 17.2 & 15.6 \\
\hline
\end{tabular}


Table 8.1 Decomposition of Employment, Unemployment and Inactivity Rate Differences: Males Excluding Students, Specification 2, LFS 1997(1)-2001(4) $)^{1,2}$

\begin{tabular}{|c|c|c|c|c|c|c|c|c|c|}
\hline & \multicolumn{3}{|c|}{ Employment } & \multicolumn{3}{|c|}{ Unemployment } & \multicolumn{3}{|c|}{ Inactivity } \\
\hline & Differential & Composition & Structure & Differential & Composition & Structure & Differential & Composition & Structure \\
\hline Northern & -0.085 & $\begin{array}{l}-0.037 \\
(43.75)\end{array}$ & $\begin{array}{c}-0.048 \\
(56.25)\end{array}$ & 0.023 & $\begin{array}{c}0.003 \\
(12.04) \\
\end{array}$ & $\begin{array}{c}0.020 \\
(87.96) \\
\end{array}$ & 0.062 & $\begin{array}{c}0.035 \\
(55.36) \\
\end{array}$ & $\begin{array}{c}0.027 \\
(44.64)\end{array}$ \\
\hline $\begin{array}{c}\text { Yorkshire } \\
\text { Humberside }\end{array}$ & -0.019 & $\begin{array}{c}-0.011 \\
(57.44)\end{array}$ & $\begin{array}{c}-0.008 \\
(42.56)\end{array}$ & 0.007 & $\begin{array}{l}0.000 \\
(2.12)\end{array}$ & $\begin{array}{c}0.007 \\
(97.88)\end{array}$ & 0.013 & $\begin{array}{c}0.011 \\
(86.27)\end{array}$ & $\begin{array}{c}0.002 \\
(13.73)\end{array}$ \\
\hline $\begin{array}{c}\text { East } \\
\text { Midlands }\end{array}$ & 0.017 & $\begin{array}{c}0.010 \\
(55.83)\end{array}$ & $\begin{array}{c}0.007 \\
(44.17)\end{array}$ & -0.007 & $\begin{array}{c}-0.004 \\
(53.27)\end{array}$ & $\begin{array}{c}-0.003 \\
(46.73)\end{array}$ & -0.010 & $\begin{array}{c}-0.006 \\
(57.71)\end{array}$ & $\begin{array}{c}-0.004 \\
(42.29)\end{array}$ \\
\hline East Anglia & 0.041 & $\begin{array}{c}0.015 \\
(37.00) \\
\end{array}$ & $\begin{array}{c}0.026 \\
(63.00) \\
\end{array}$ & -0.012 & $\begin{array}{l}-0.003 \\
(28.11) \\
\end{array}$ & $\begin{array}{l}-0.009 \\
(71.89) \\
\end{array}$ & -0.028 & $\begin{array}{l}-0.012 \\
(40.82)\end{array}$ & $\begin{array}{l}-0.016 \\
(59.18)\end{array}$ \\
\hline London & -0.011 & $\begin{array}{c}-0.016 \\
(147.50)\end{array}$ & $\begin{array}{c}0.005 \\
(-47.50)\end{array}$ & 0.017 & $\begin{array}{c}0.020 \\
(115.10)\end{array}$ & $\begin{array}{c}-0.003 \\
(-15.10)\end{array}$ & -0.006 & $\begin{array}{c}-0.003 \\
(53.63)\end{array}$ & $\begin{array}{l}-0.003 \\
(46.37)\end{array}$ \\
\hline South East & 0.074 & $\begin{array}{c}0.044 \\
(59.29) \\
\end{array}$ & $\begin{array}{c}0.030 \\
(40.71) \\
\end{array}$ & -0.023 & $\begin{array}{l}-0.010 \\
(41.82) \\
\end{array}$ & $\begin{array}{c}-0.013 \\
(58.18) \\
\end{array}$ & -0.051 & $\begin{array}{l}-0.034 \\
(67.17) \\
\end{array}$ & $\begin{array}{c}-0.017 \\
(32.83) \\
\end{array}$ \\
\hline South West & 0.041 & $\begin{array}{c}0.023 \\
(55.60) \\
\end{array}$ & $\begin{array}{c}0.018 \\
(44.40) \\
\end{array}$ & -0.016 & $\begin{array}{l}-0.009 \\
(55.28)\end{array}$ & $\begin{array}{c}-0.007 \\
(44.72)\end{array}$ & -0.025 & $\begin{array}{c}-0.014 \\
(55.80) \\
\end{array}$ & $\begin{array}{c}-0.011 \\
(44.20)\end{array}$ \\
\hline $\begin{array}{c}\text { West } \\
\text { Midlands }\end{array}$ & 0.005 & $\begin{array}{c}-0.011 \\
(-202.15)\end{array}$ & $\begin{array}{c}0.016 \\
(302.15)\end{array}$ & 0.002 & $\begin{array}{c}0.003 \\
(122.49)\end{array}$ & $\begin{array}{c}-0.001 \\
(-22.49)\end{array}$ & -0.008 & $\begin{array}{c}0.008 \\
(-102.62)\end{array}$ & $\begin{array}{c}-0.016 \\
(202.62)\end{array}$ \\
\hline North West & -0.041 & $\begin{array}{l}-0.013 \\
(32.33) \\
\end{array}$ & $\begin{array}{l}-0.028 \\
(67.67) \\
\end{array}$ & 0.006 & $\begin{array}{l}-0.000 \\
(-1.08) \\
\end{array}$ & $\begin{array}{c}0.006 \\
(101.08) \\
\end{array}$ & 0.035 & $\begin{array}{c}0.013 \\
(37.62) \\
\end{array}$ & $\begin{array}{c}0.022 \\
(62.38) \\
\end{array}$ \\
\hline Wales & -0.069 & $\begin{array}{c}-0.032 \\
(46.48)\end{array}$ & $\begin{array}{c}-0.037 \\
(53.52)\end{array}$ & 0.009 & $\begin{array}{c}-0.002 \\
(-19.61)\end{array}$ & $\begin{array}{c}0.011 \\
(119.61)\end{array}$ & 0.060 & $\begin{array}{c}0.034 \\
(56.64)\end{array}$ & $\begin{array}{c}0.026 \\
(43.36)\end{array}$ \\
\hline Scotland & -0.038 & $\begin{array}{l}-0.018 \\
(48.99)\end{array}$ & $\begin{array}{l}-0.020 \\
(51.01)\end{array}$ & 0.014 & $\begin{array}{c}0.004 \\
(31.19)\end{array}$ & $\begin{array}{c}0.010 \\
(68.81)\end{array}$ & 0.024 & $\begin{array}{c}0.014 \\
(59.04)\end{array}$ & $\begin{array}{c}0.010 \\
(40.96)\end{array}$ \\
\hline
\end{tabular}

1. All entries outside parentheses rounded to three decimal places.

2. Figures in parentheses indicate the percentage of the raw differential attributed to each component. 
Table 8.2 Breakdown of Composition Effect: Specification 2, Males

\begin{tabular}{|c|c|c|c|c|c|c|c|c|c|}
\hline & \multicolumn{3}{|c|}{ Northern } & \multicolumn{3}{|c|}{ Yorkshire and Humberside } & \multicolumn{3}{|c|}{ East Midlands } \\
\hline & Employment & Inactivity & Unemployment & Employment & Inactivity & Unemployment & Employment & Inactivity & Unemployment \\
\hline Age & 3.99 & 5.05 & 0.83 & -4.44 & -6.66 & 0.45 & -11.15 & -11.52 & -0.60 \\
\hline Marital Status & 0.30 & 0.38 & 0.28 & -2.70 & -4.05 & -0.42 & 17.40 & 17.99 & 19.99 \\
\hline Qualifications & 2.94 & 3.72 & 2.44 & 11.01 & 16.52 & 1.40 & -11.76 & -12.16 & -11.21 \\
\hline Head/Household & -0.03 & -0.04 & -0.01 & -.13 & 0.20 & 0.01 & -0.66 & -0.68 & -0.27 \\
\hline Housing Tenure & 9.66 & 12.22 & 6.17 & 6.60 & 9.91 & 0.13 & 30.68 & 31.72 & 34.30 \\
\hline Children & -0.12 & -0.15 & -0.18 & -0.91 & -1.37 & -0.13 & 2.05 & 2.12 & 1.26 \\
\hline Ethnicity & -4.00 & -5.06 & -3.50 & -4.99 & -7.49 & $\begin{array}{l}-0.71 \\
\end{array}$ & 4.68 & 4.84 & 4.96 \\
\hline Month and Year & 0.33 & 0.41 & 0.47 & -0.74 & -1.12 & -0.17 & -1.38 & -1.42 & -0.84 \\
\hline \multirow[t]{3}{*}{ Ill Health } & 30.68 & 38.82 & 5.54 & 53.52 & 80.34 & 1.57 & 25.96 & 26.83 & 5.68 \\
\hline & \multicolumn{3}{|c|}{ East Anglia } & \multicolumn{3}{|c|}{ London } & \multicolumn{3}{|c|}{ South East } \\
\hline & Employment & Inactivity & Unemployment & Employment & Inactivity & Unemployment & Employment & Inactivity & Unemployment \\
\hline Age & -6.29 & -6.94 & -1.16 & -191.31 & -72.15 & -5.98 & -2.47 & -2.80 & 1.23 \\
\hline Marital Status & 5.62 & 6.20 & 7.37 & 89.56 & 33.78 & 27.05 & 4.48 & 5.08 & 6.35 \\
\hline Qualifications & 0.90 & 0.99 & -1.95 & -20.35 & -7.68 & -3.56 & 5.78 & 6.55 & 6.20 \\
\hline Head/Household & -0.29 & -0.32 & -0.14 & -2.06 & -0.78 & -0.22 & -0.19 & -0.21 & -0.10 \\
\hline Housing Tenure & 6.12 & 6.76 & 6.43 & 189.71 & 71.55 & 51.43 & 21.48 & 24.33 & 17.74 \\
\hline Children & 0.27 & 0.30 & 0.84 & 9.07 & 3.42 & 1.91 & -0.18 & -0.20 & -0.53 \\
\hline Ethnicity & 9.45 & 10.42 & 11.43 & 184.77 & 69.69 & 51.48 & 2.61 & 2.95 & 3.41 \\
\hline Month and Year & 0.81 & 0.89 & 0.20 & -0.80 & -0.30 & -0.64 & 0.13 & 0.15 & 0.03 \\
\hline \multirow[t]{3}{*}{ Ill Health } & 20.41 & 22.52 & 5.10 & -111.08 & -41.90 & -6.39 & 27.65 & 31.32 & 7.47 \\
\hline & \multicolumn{3}{|c|}{ South West } & \multicolumn{3}{|c|}{ West Midlands } & \multicolumn{3}{|c|}{ North West } \\
\hline & Employment & Inactivity & Unemployment & Employment & Inactivity & Unemployment & Employment & Inactivity & Unemployment \\
\hline Age & -13.74 & -13.79 & 0.57 & -29.34 & -14.90 & 9.86 & 0.41 & 0.48 & -0.25 \\
\hline Marital Status & 7.90 & 7.93 & 9.35 & 9.71 & 4.93 & -13.23 & 5.28 & 6.14 & -0.96 \\
\hline Qualifications & 12.63 & 12.67 & 10.04 & -68.75 & -34.90 & 65.54 & 6.14 & 7.14 & -0.55 \\
\hline Head/Household & -0.40 & -0.40 & -0.17 & 1.81 & 0.92 & -0.89 & -0.25 & -0.30 & 0.02 \\
\hline Housing Tenure & 26.76 & 26.86 & 21.08 & -44.21 & -22.44 & -2.27 & 0.19 & 0.22 & 0.76 \\
\hline Children & -0.31 & -0.31 & -0.40 & -2.24 & -1.14 & 3.23 & 0.13 & 0.14 & 0.03 \\
\hline Ethnicity & 10.24 & 10.27 & 11.18 & -32.21 & -16.35 & 40.51 & -3.34 & -3.88 & 0.56 \\
\hline Month and Year & 0.19 & 0.19 & 0.86 & -2.97 & -1.51 & 10.93 & -0.23 & -0.26 & 0.14 \\
\hline \multirow[t]{3}{*}{ Ill Health } & 12.34 & 12.38 & 2.78 & -33.95 & -17.24 & 8.81 & 24.00 & 27.93 & -0.83 \\
\hline & \multicolumn{3}{|c|}{ Wales } & \multicolumn{3}{|c|}{ Scotland } & & & \\
\hline & Employment & Inactivity & Unemployment & Employment & Inactivity & Unemployment & & & \\
\hline Age & 8.05 & 9.77 & -2.72 & 1.31 & 1.58 & 1.47 & & & \\
\hline Marital Status & 0.28 & 0.34 & -0.75 & 5.46 & 6.58 & 6.10 & & & \\
\hline Qualifications & 7.65 & 9.28 & -11.70 & -6.55 & -7.90 & -4.36 & & & \\
\hline Head/Household & -0.13 & -0.16 & 0.13 & -0.10 & -0.11 & -0.04 & & & \\
\hline Housing Tenure & 7.36 & 8.93 & -1.44 & 42.49 & 51.21 & 37.11 & & & \\
\hline Children & -0.21 & -0.25 & 0.67 & -2.37 & -2.86 & $\begin{array}{l}-2.38 \\
\end{array}$ & & & \\
\hline Ethnicity & -4.07 & -4.93 & 10.09 & -11.47 & -13.82 & -11.85 & & & \\
\hline Month and Year & -0.14 & -0.17 & 0.39 & 0.67 & 0.80 & 0.97 & & & \\
\hline Ill Health & 27.89 & 33.84 & -14.29 & 19.55 & 23.56 & 4.17 & & & \\
\hline
\end{tabular}

Note: Entry in the table is the percentage of the raw difference attributable to each characteristic. 
Table 9.1 Decomposition of Employment, Unemployment and Inactivity Rate Differences: Females Excluding Students, Specification 2, LFS 1997(1)-2001(4) ${ }^{1,2}$

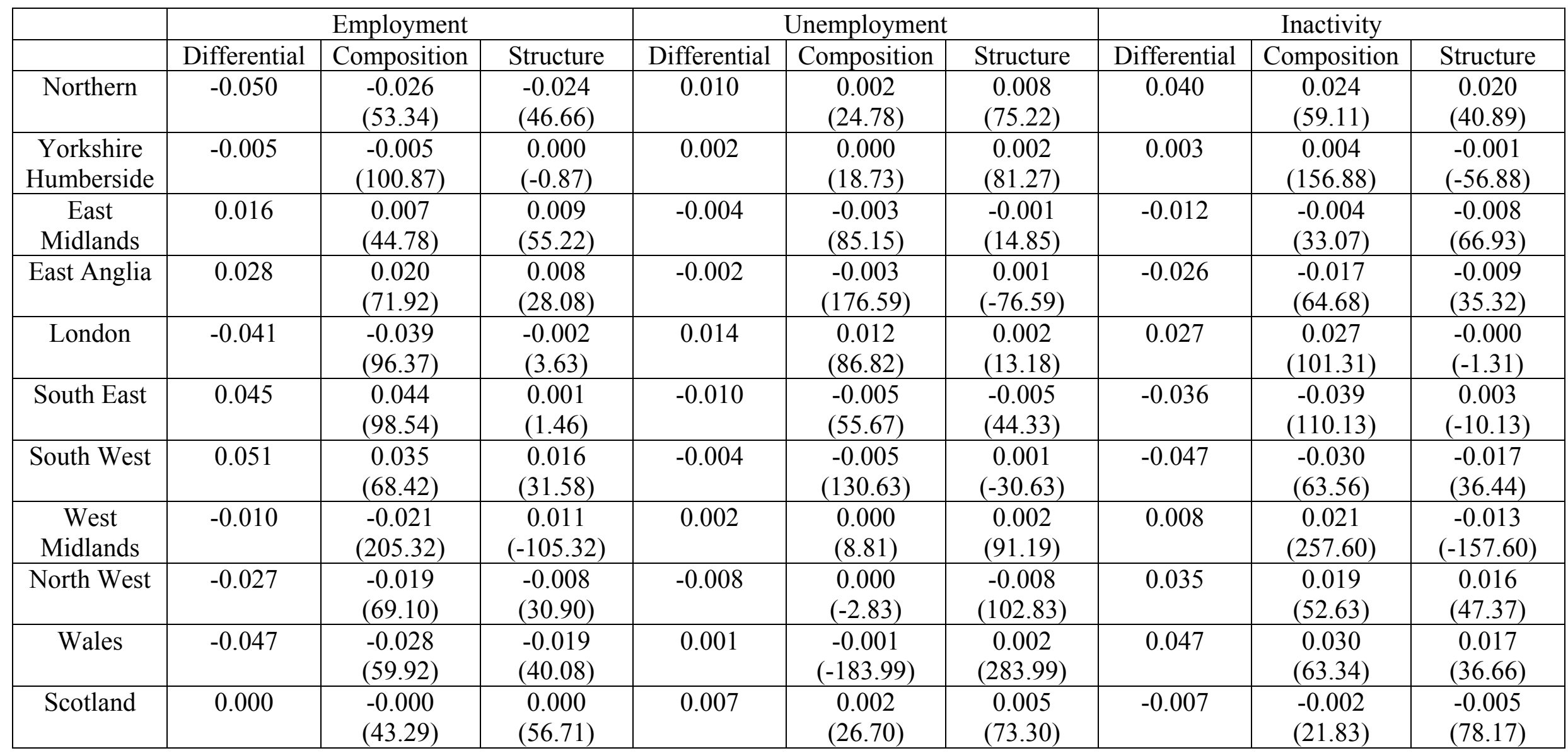

Notes:

1. All entries outside parentheses rounded to three decimal places

2. Figures in parentheses indicate the percentage of the raw differential attributed to each component. 
Table 9.2 Breakdown of Composition Effect: Specification 2, Females

\begin{tabular}{|c|c|c|c|c|c|c|c|c|c|}
\hline & \multicolumn{3}{|c|}{ Northern } & \multicolumn{3}{|c|}{ Yorkshire and Humberside } & \multicolumn{3}{|c|}{ East Midlands } \\
\hline & Employment & Inactivity & Unemployment & Employment & Inactivity & Unemployment & Employment & Inactivity & Unemployment \\
\hline Age & 0.45 & 0.50 & 3.16 & -24.88 & -38.70 & 21.03 & -10.01 & -7.39 & 2.29 \\
\hline Marital Status & -2.20 & -2.48 & 1.75 & 7.76 & 12.07 & -4.13 & -22.62 & -16.71 & 20.15 \\
\hline Qualifications & 26.21 & 29.60 & 7.05 & 130.79 & 203.40 & 19.92 & -85.68 & -63.28 & -25.60 \\
\hline Head/Household & 1.84 & 2.08 & 0.48 & -11.32 & -17.60 & -1.49 & 22.52 & 16.64 & 5.15 \\
\hline Housing Tenure & 11.12 & 12.56 & 11.58 & 0.78 & 1.21 & -3.54 & 64.74 & 47.81 & 57.06 \\
\hline Children & -2.49 & -2.81 & -0.51 & -42.60 & -66.25 & -6.01 & 21.47 & 15.86 & 5.01 \\
\hline Ethnicity & -13.27 & -14.98 & -10.05 & -52.01 & -80.88 & -19.74 & 20.55 & 15.18 & 13.57 \\
\hline Month and Year & 0.41 & 0.46 & 1.45 & -1.74 & -2.71 & -2.67 & 0.73 & 0.54 & -1.88 \\
\hline \multirow[t]{3}{*}{ Ill Health } & 30.27 & 34.18 & 9.87 & 94.08 & 146.32 & 15.37 & 33.09 & 24.44 & 9.40 \\
\hline & \multicolumn{3}{|c|}{ East Anglia } & \multicolumn{3}{|c|}{ London } & \multicolumn{3}{|c|}{ South East } \\
\hline & Employment & Inactivity & Unemployment & Employment & Inactivity & Unemployment & Employment & Inactivity & Unemployment \\
\hline Age & -23.92 & -21.49 & 2.37 & -36.03 & -37.88 & 1.69 & -5.38 & -6.01 & 3.52 \\
\hline Marital Status & -15.32 & -13.77 & 36.47 & -17.44 & -18.34 & 10.71 & -7.14 & -7.98 & 5.88 \\
\hline Qualifications & -9.11 & -8.18 & -14.41 & -28.76 & -30.24 & 0.76 & 30.20 & 33.75 & 7.97 \\
\hline Head/Household & 17.32 & 15.56 & 11.76 & 19.82 & 20.83 & 3.00 & 7.22 & 8.07 & 1.64 \\
\hline Housing Tenure & 14.91 & 13.40 & 46.88 & 57.55 & 60.49 & 31.64 & 34.54 & 38.60 & 22.01 \\
\hline Children & 42.51 & 38.20 & 28.66 & 23.51 & 24.71 & 2.50 & -1.81 & -2.02 & -0.65 \\
\hline Ethnicity & 26.07 & 23.43 & 51.11 & 88.61 & 93.15 & 38.76 & 9.05 & 10.12 & 5.95 \\
\hline Month and Year & -0.49 & -0.44 & -3.11 & -0.22 & -0.23 & -0.24 & 0.15 & 0.16 & 0.39 \\
\hline \multirow[t]{3}{*}{ Ill Health } & 20.00 & 17.97 & 16.87 & -10.65 & -11.20 & -2.01 & 31.72 & 35.45 & 8.97 \\
\hline & \multicolumn{3}{|c|}{ South West } & \multicolumn{3}{|c|}{ West Midlands } & \multicolumn{3}{|c|}{ North West } \\
\hline & Employment & Inactivity & Unemployment & Employment & Inactivity & Unemployment & Employment & Inactivity & Unemployment \\
\hline Age & -8.31 & -7.72 & 5.42 & 14.74 & 18.49 & 0.52 & 1.76 & 1.34 & -0.25 \\
\hline Marital Status & -5.67 & -5.27 & 14.35 & 9.62 & 12.07 & -1.40 & $\begin{array}{l}-9.22 \\
\end{array}$ & $\begin{array}{l}-7.02 \\
\end{array}$ & -1.19 \\
\hline Qualifications & 26.07 & 24.22 & 26.42 & 88.43 & 110.94 & 4.34 & 32.30 & 24.61 & -1.06 \\
\hline Head/Household & 5.64 & 5.24 & 3.73 & -16.12 & -20.22 & $\begin{array}{l}-0.67 \\
\end{array}$ & 9.35 & 7.12 & $\begin{array}{l}-0.37 \\
\end{array}$ \\
\hline Housing Tenure & 17.08 & 15.87 & 39.52 & 3.98 & 5.00 & -2.12 & 4.39 & 3.34 & 0.44 \\
\hline Children & 5.23 & 4.86 & 1.86 & 35.51 & 44.55 & 1.57 & 12.42 & 9.46 & -0.55 \\
\hline Ethnicity & 14.34 & 13.33 & 27.42 & 32.38 & 40.62 & 3.87 & -10.18 & -7.76 & 1.15 \\
\hline Month and Year & -0.04 & -0.03 & 0.32 & 3.08 & 3.87 & 0.95 & $\begin{array}{l}-1.09 \\
\end{array}$ & -0.83 & 0.41 \\
\hline \multirow[t]{3}{*}{ Ill Health } & 14.07 & 13.08 & 11.58 & 33.70 & 42.28 & 1.73 & 29.37 & 22.37 & -1.43 \\
\hline & \multicolumn{3}{|c|}{ Wales } & \multicolumn{3}{|c|}{ Scotland } & & & \\
\hline & Employment & Inactivity & Unemployment & Employment & Inactivity & Unemployment & & & \\
\hline Age & 8.31 & 8.79 & 53.01 & -4.67 & 2.36 & 1.19 & & & \\
\hline Marital Status & -0.93 & -0.98 & -6.92 & -19.40 & 9.78 & 11.91 & & & \\
\hline Qualifications & 19.13 & 20.22 & $\begin{array}{l}-105.01 \\
\end{array}$ & -18.57 & 9.36 & -15.21 & & & \\
\hline Head/Household & 1.77 & 1.87 & -12.05 & 19.19 & -9.68 & 3.26 & & & \\
\hline Housing Tenure & 10.58 & 11.18 & -80.21 & 97.81 & -49.32 & 65.76 & & & \\
\hline Children & $\begin{array}{l}4.24 \\
\end{array}$ & $\begin{array}{ll}4.48 \\
\end{array}$ & -38.32 & -87.56 & 44.16 & -15.36 & & & \\
\hline Ethnicity & -12.65 & -13.37 & 248.75 & -72.91 & 36.77 & -35.73 & & & \\
\hline Month and Year & 0.17 & 0.18 & 4.78 & 1.07 & -0.54 & 2.08 & & & \\
\hline Ill Health & 29.31 & 30.98 & -248.04 & 41.75 & -21.05 & 8.80 & & & \\
\hline
\end{tabular}

Note: Entry in the table is the percentage of the raw difference attributable to each characteristic. 